\title{
Synthesis of 1,4-phenylene bridged bis-heterocyclic compounds
}

\author{
Raafat M. Shaker \\ Chemistry Department, College of Science, Al-Jouf University, \\ Sakaka, Kingdom of Saudi Arabia \\ E-mail: rmshaker@yahoo.com
}

\section{Abstract}

The synthesis of 1,4-phenylene bis-heterocyclic compounds is comprehensively reviewed.

Keywords: Synthesis, 1,4-phenylene, bis-heterocyclic compounds, terephthalaldehyde

\section{Contents}

1. Introduction

2. Five-membered Rings with One Heteroatom

2.1. 1,4-Phenylene-bis-furans and their fused derivatives

2.2. 1,4-Phenylene-bis-thiophenes

2.3. 1,4-Phenylene-bis-pyrroles

3. Five-membered Rings with Two Heteroatoms

3.1. 1,4-Phenylene-bis-pyrazoles and their fused derivatives

3.2. 1,4-Phenylene-bis-imidazoles and their fused derivatives

3.3. 1,4-Phenylene-bis-oxazoles

3.4. 1,4-Phenylene-bis-isoxazoles

3.5. 1,4-Phenylene-bis-thiazoles and their fused derivatives

4. Five-membered Rings with Three Heteroatoms

4.1. 1,4-Phenylene-bis-triazoles and their fused derivatives

4.2. 1,4-Phenylene-bis-dioxazoles

4.3. 1,4-Phenylene-bis-oxadiazoles

4.4. 1,4-Phenylene- is-thiadiazoles

5. Five-membered Rings with Four Heteroatoms

5.1. 1,4-Phenylene-bis-tetrazoles

6. Six-membered Rings with One Heteroatom

6.1. 1,4-Phenylene-bis-pyrans and their fused derivatives

6.2. 1,4-Phenylene-bis-thiopyrans 
6.3. 1,4-Phenylene-bis-pyridines and their fused derivatives

7. Six-membered Rings with Two Heteroatoms

7.1. 1,4-Phenylene-bis-pyrimidines and their fused derivatives

7.2. 1,4-Phenylene-bis-oxazines

7.3. 1,4-Phenylene-bis-pyrazines

7.4. 1,4-Phenylene-bis-1,3-thiazines and their fused derivatives

8. 1,4-Phenylene- Bis-spiroheterocycles

9. Conclusions

10. References

\section{Introduction}

Heterocyclic chemistry comprises at least half of all organic chemistry research worldwide. The large number of biologically active molecules that contain heterocyclic rings has made synthetic studies of new heterocyclic rings very attractive, ${ }^{1-5}$ particularly, polyfunctionalized heterocyclic compounds play important roles in the drug discovery process, and analysis of drugs in late development or on the market shows that $68 \%$ of them are heterocycles. ${ }^{6-12}$ Therefore, it is not surprising that research on the synthesis of polyfunctionalized heterocyclic compounds has received significant attention. In recent years, attention has been increasingly paid to the synthesis of bis-heterocyclic compounds which exhibit various biological activities, ${ }^{13-20}$ including antibacterial, fungicidal, tuberculostatic, antiamoebic, and plant growth regulative properties. The current first specialized review covers the synthesis of 1,4-phenylene-bisheterocyclic compounds from the late 1972 until 2011, and our survey of the literature on the synthesis of these heterocyclic has been divided according to the number of heteroatom in the heterocyclic.

\section{Five-membered Rings with One Heteroatom}

\subsection{1,4-Phenylene-bis-furans and their fused derivatives}

Terephthalaldehyde $\mathbf{1}$ when treated with two equivalents of dimethyl acetylenedicarboxylate (DMAD) 2 and methoxytriazoline 3 afforded both mono- and bis-adducts $\mathbf{4}$ and 5, respectively, (Scheme 1). ${ }^{21}$

The 5,5'-(1,4-phenylene)bis(furo[2,3- $d]$ pyrimidine-2,4(1H,3H)-dione) derivatives 8 were obtained from the reaction of isocyanides $\mathbf{6}$, terephthalaldehyde $\mathbf{1}$ and $N, N$-dimethylbarbituric acid 7 via efficient one-pot three-component condensation reactions (Scheme 2). ${ }^{22}$ 


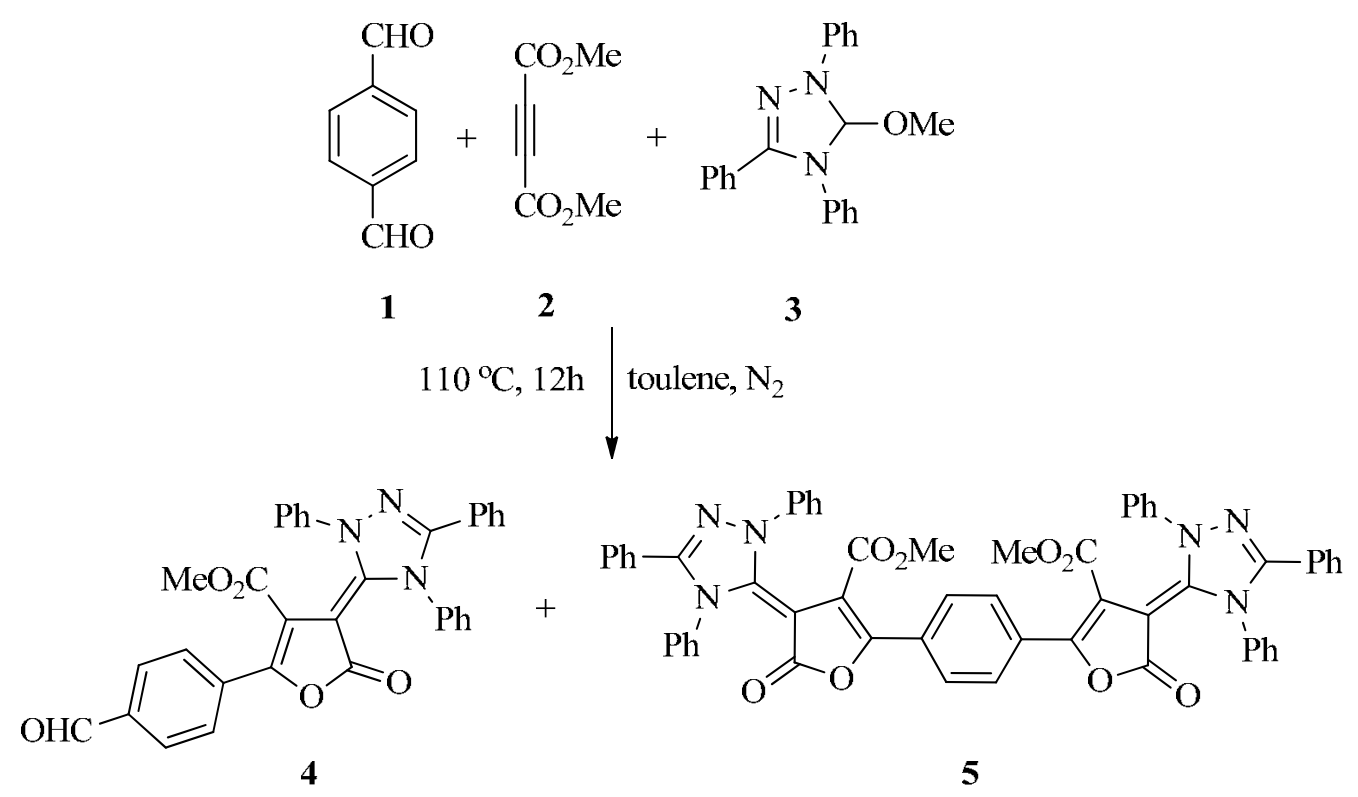

\section{Scheme 1}<smiles>[R]Nc1oc2c(c1-c1ccc(-c3c(N[R])oc4c3c(=O)n(C)c(=O)n4C)cc1)c(=O)n(C)c(=O)n2C</smiles>

\section{Scheme 2}

\subsection{1,4-Phenylene-bis-thiophenes}

The 1,4-bis(thiophen-2-yl)benzene 11 was synthesized according to the procedure reported by Yang et al. ${ }^{23}$ As shown in Scheme, 3, 2-bromothiophene 9 is reacted with magnesium to afford Grignard reagents $\mathbf{1 0}$ which are then cross-coupled to 1,4-dibromobenzene in the presence of catalytic bis(triphenylphosphino)dichloronickel (II) $\left(\mathrm{NiCl}_{2}\left(\mathrm{PPh}_{3}\right)_{2}\right)($ Scheme 3).

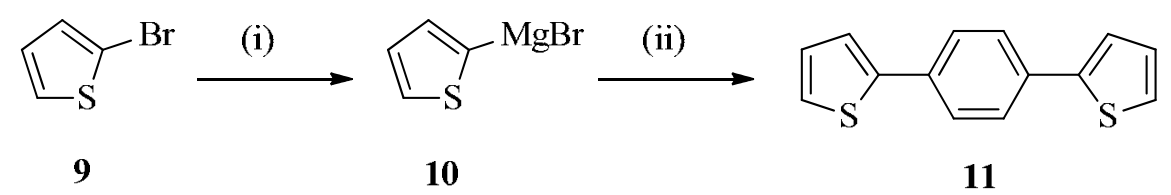

Scheme 3. Reagents: (i) $\mathrm{Mg}, \mathrm{Et}_{2} \mathrm{O}$; (ii) 1,,4-dibromobenzere, $\mathrm{NiCI}_{2}\left(\mathrm{PPh}_{3}\right)_{2}, \mathrm{THF}$. 
Suzuki cross-couplings onto the isomeric 1,4-dibromo-2,5-diiodobenzene 12 afforded the thienyl-substituted terphenyl 13 (Scheme 4). ${ }^{24}$

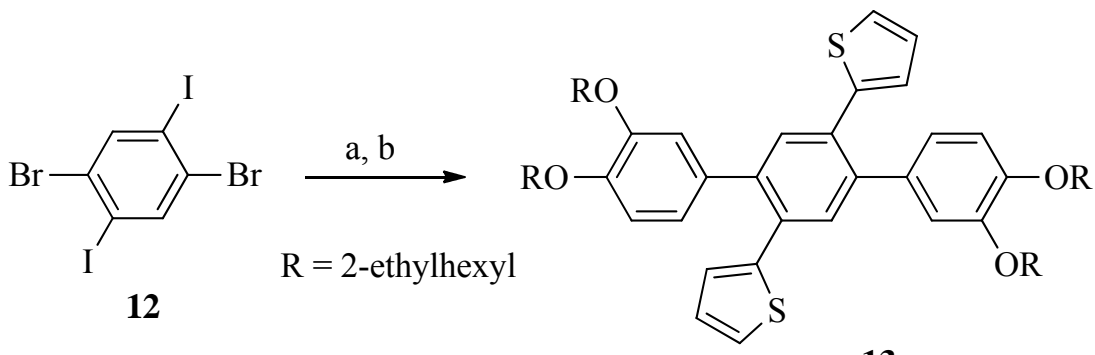

13

Scheme 4. Reagents: (a) 2-tridutylstannythiopene, $\left(\mathrm{Ph}_{3} \mathrm{P}\right)_{2} \mathrm{PdCI}_{2}, \mathrm{DMF}, 80{ }^{\circ} \mathrm{C}$. (b) 3,4-di (2-tthylhexyloxy)phenylpinacolatoborane, $\mathrm{Pd}\left(\mathrm{PPh}_{3}\right)_{4}, \mathrm{Na}_{2} \mathrm{CO}_{3}, \mathrm{PhMe}, \mathrm{EtOH}, \mathrm{H}_{2} \mathrm{O}, 90{ }^{\circ} \mathrm{C}$.

\subsection{1,4-Phenylene-bis-pyrroles}

The 1,4-bis(1H-pyrrol-2-yl)benzene derivatives 18 were prepared by modification of the method of Engel and Steglich, ${ }^{25}$ in accordance with the general pathway set out in Scheme 5 . The acid chlorides 14 were reacted with allylamine 15 to give aryl bis(allylamides) 16. Subsequent treatment with phosgene furnished the aryl bis(allylimino chlorides) 17, which were used without isolation or purification in the following step. Compounds $\mathbf{1 7}$ were cyclized under basic conditions to form 18 (Scheme 5). ${ }^{26,27}$


\section{Scheme 5}

The 1,4-bis(1-vinyl-1H-pyrrol-2-yl)benzene 20 was synthesized by the Trofimov reaction from 1,4-diacetylbenzene dioxime 19 and acetylene in a $\mathrm{KOH}$ - DMSO system (Scheme 6). ${ }^{28-30}$ 


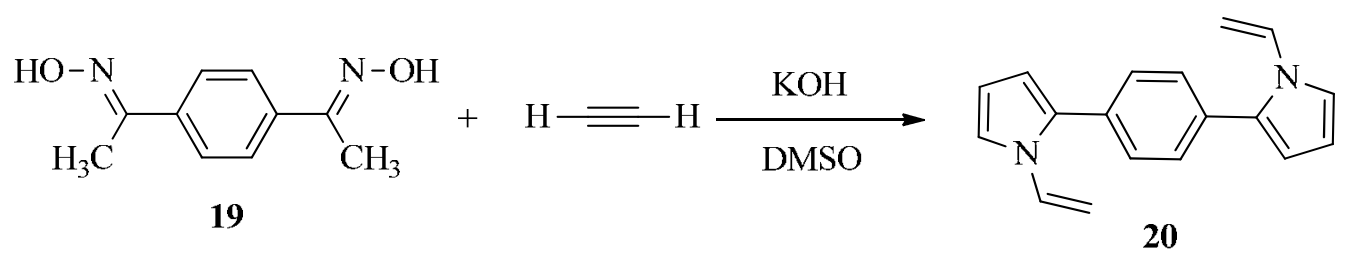

\section{Scheme 6}

When a mixture of 3,4-diethyl-2-ethoxycarbonyl-5-iodopyrrole 21 (2.0 mmol), 1,4phenylene-bisboronic acid 22 (1.0 mmol), $\mathrm{K}_{2} \mathrm{CO}_{3}$ (6.6 mol), $\mathrm{Pd}(\mathrm{OAc})_{2}(0.10 \mathrm{mmol})$, and $\mathrm{PPh}_{3}$ $(0.20 \mathrm{mmol})$ in ethanol was heated under argon for $24 \mathrm{~h}$ at reflux, diethyl 5,5'-(1,4phenylene)bis(3,4-diethyl-1H-pyrrole-2-carboxylate) 23 was obtained (Scheme 7). ${ }^{31}$<smiles></smiles>

\section{Scheme 7}

The oxidative electropolymerization of these 1,4-bis( $1 H$-pyrrol-2-yl)benzene $18(\mathrm{R}=\mathrm{H})$ gave the polymer 24 (Figure 1). ${ }^{26,27}$

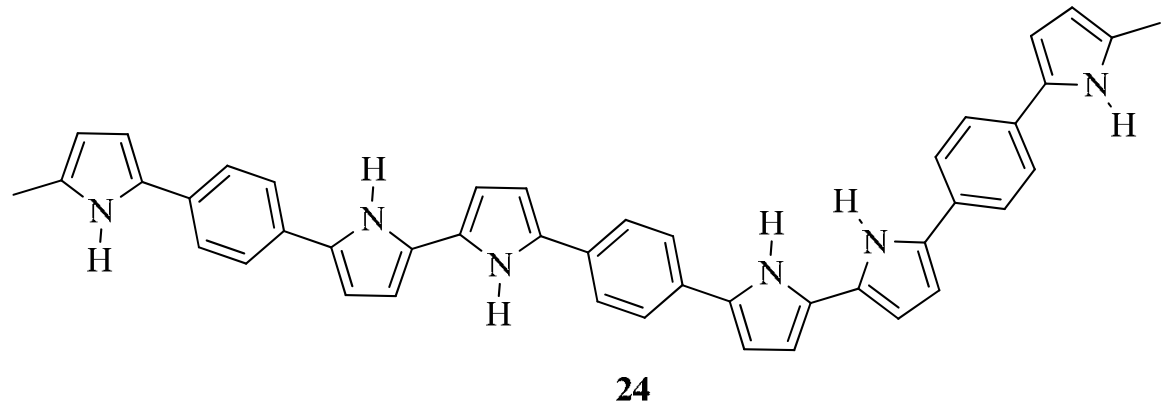

\section{Figure 1}

In the reaction of 1,4-diaminobenzene 25 with methyl 4-methoxy-6-oxo-7,7,7-trifluoro-4heptenoate 26 in a stoichiometric ratio 2:1 mol-equiv ratio in $\mathrm{MeCN}$ under reflux conditions the intramolecular cyclisation took place with the formation of 1,1'-(1,4-phenylene)bis(5-(3,3,3trifluoro-2-oxopropylidene)pyrrolidin-2-one) 27 (Scheme 8). ${ }^{32}$ 


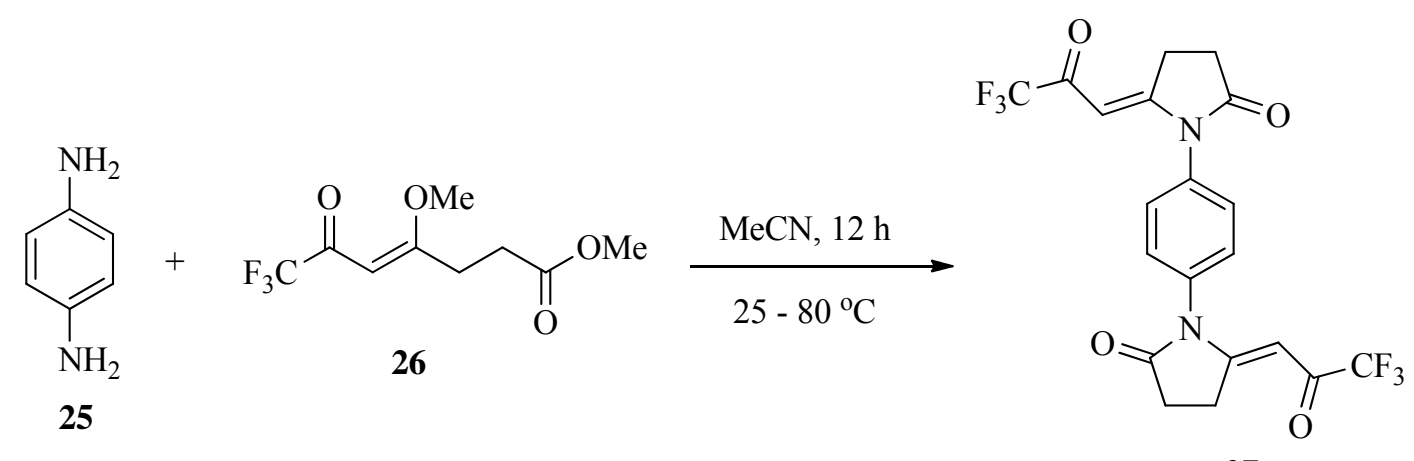

27

\section{Scheme 8}

The reaction of cis-1,2,3,6-tetrahydrophthalic anhydride $\mathbf{2 8}$ and maleic anhydride $\mathbf{2 9}$ with 1,4-diaminobenzene 25 on montmorillonite K-10 under microwave irradiation afforded 2,2'-(1,4phenylene)bis(isoindoline-1,3-dione) $\mathbf{3 0}$ and 1,1'-(1,4-phenylene)bis(1H-pyrrole-2,5-dione) 31, respectively (Scheme 9). ${ }^{33}$

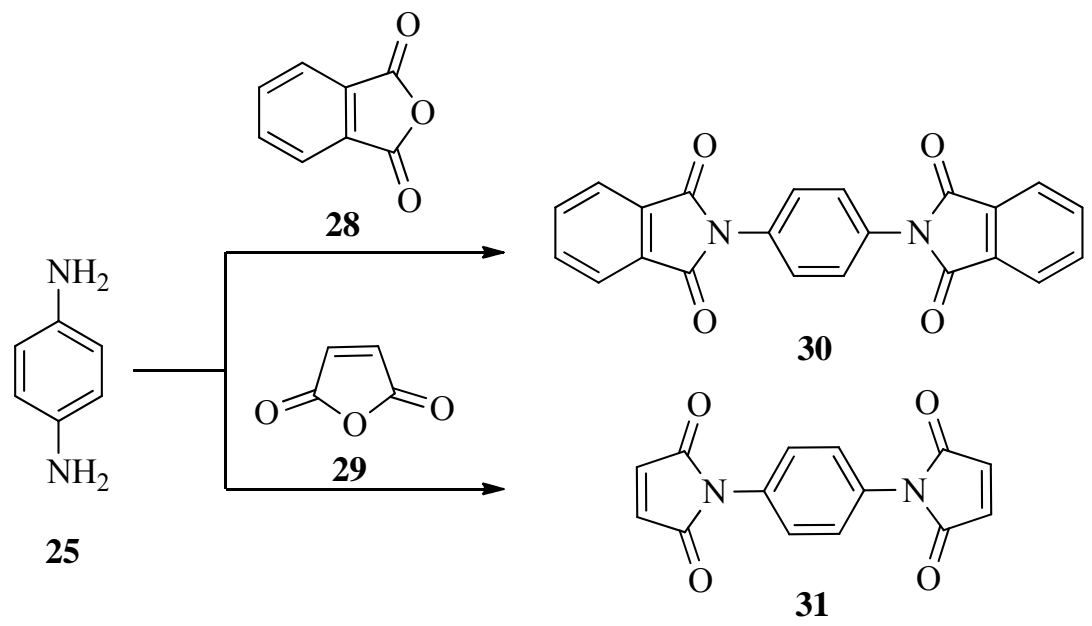

\section{Scheme 9}

The Knorr-Paal reaction 1,4-diaminobenzene 25 with 1,4-bis(2-thienyl)-1,4-butanedione 32 in the presence of propionic acid catalysts afforded 1,4-bis[2,5-di(2-thienyl)-1H-1pyrrolyl]benzene 33 (Scheme 10). ${ }^{34}$ 


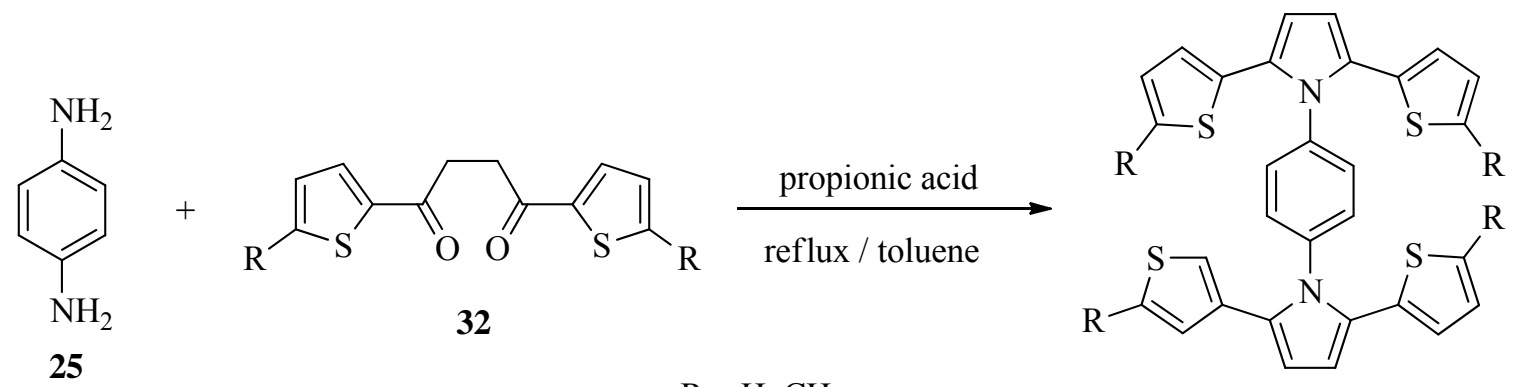

$$
\mathrm{R}=\mathrm{H}, \mathrm{CH}_{3}
$$

33

\section{Scheme 10}

\section{Five-membered Rings with Two Heteroatoms}

\subsection{1,4-Phenylene-bis-pyrazoles and their fused derivatives}

In the reaction between diarylidene-1,4-diacetylbenzenes $\mathbf{3 4}$ and phenylhydrazine hydrochloride, 1,4-bis(4,5-dihydro-1 $H$-pyrazol-3-yl)benzene derivatives 35 were obtained which possess a bright green or blue luminescence (Figure 2). ${ }^{35}$

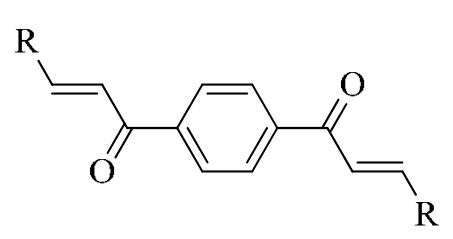

34

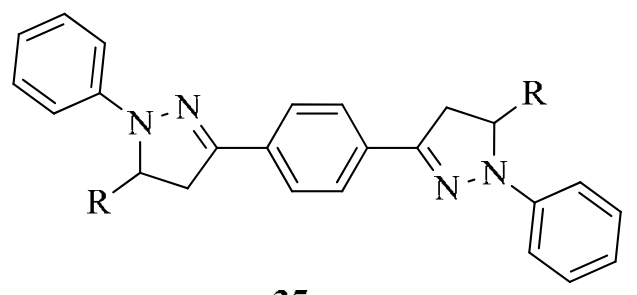

35

\section{Figure 2}

The cyclization of bischalcone 36 with $N-4$ substituted-thiosemicarbazides 37 under basic condition led to the formation of 5,5'-(1,4-phenylene)bis(4,5-dihydro-1H-pyrazole-1carbothioamide) 38 (Scheme 11). ${ }^{18}$

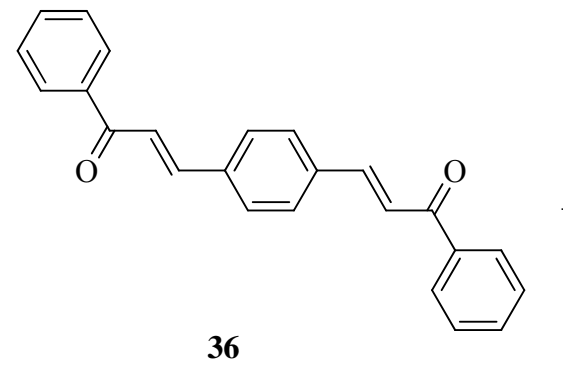

Scheme 11

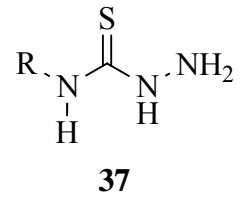

37

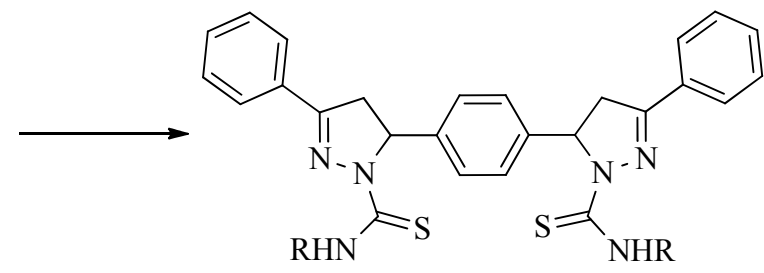

38 
The 5,5'-(1,4-phenylene)bis(3-aryl-1H-pyrazole) 39 are synthesized by the reaction of bischalcone 35 with hydrazine hydrate catalyzed by anhydrous sodium acetate/acetic anhydride under ultrasonic irradiation method at $45^{\circ} \mathrm{C}$ within 10-20 min (Figure 3). ${ }^{36}$

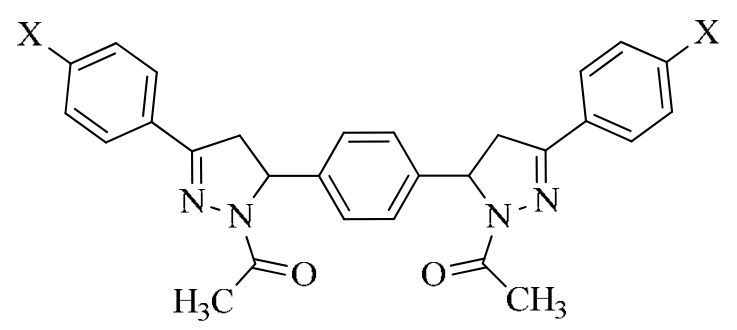

$39\left(\mathrm{X}=\mathrm{H}, \mathrm{Cl}, \mathrm{Br}, \mathrm{CH}_{3}, \mathrm{OCH}_{3}\right)$

\section{Figure 3}

The anodic oxidation of 4-tert-butylcatecol $\mathbf{4 0}$ in the presence of pyrazol-5-ones $\mathbf{4 1}$ in 2:1 volume ratio of acetate buffer to acetonitrile, gave 4,4'-(1,4-phenylene)bis(1-aryl-3-methyl-1Hpyrazol-5-ol) 42 (Scheme 12). ${ }^{37}$<smiles>[Y20]C=C(C)C(C)(C)C(=O)OC</smiles>

\section{Scheme 12}

The 1,2,4-tris(1H-pyrazolyl)benzene $\mathbf{4 5}$ was synthesized by the reaction of 2,4difluoroiodobenzene 43 with pyrazole 44 catalyzed by $\mathrm{Cu}_{2} \mathrm{O}(5 \mathrm{~mol} \%) 20 \%$ salicylaldoxime (20 mol\%) and $\mathrm{Cs}_{2} \mathrm{CO}_{3}$ (2 equiv) in acetonitrile (Scheme 13). ${ }^{38}$

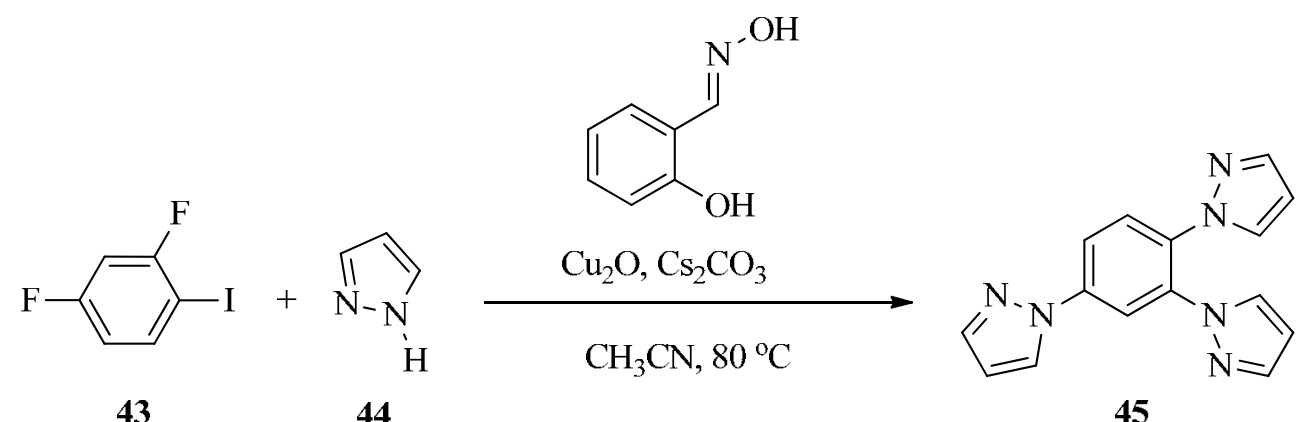

\section{Scheme 13}


Also, the 1,1'-(2,5-difluoro-1,4-phenylene)bis(1H-pyrazole) $\quad \mathbf{4 6},{ }^{39} \quad 1,1^{\prime}$-(perfluoro-1,4phenylene)bis(1H-pyrazole) $\quad \mathbf{4 7}^{39} \quad 1,2,3,4$-tetrakis(pyrazol-1-yl)benzene $\quad \mathbf{4 8},{ }^{39} \quad 1,2,4,5$ tetrakis(pyrazol-1-yl)benzene $\mathbf{4 9},{ }^{39,40}$ 1,4-difluoro-2,3,5,6-tetrakis(pyrazol-1-yl)benzene $\mathbf{5 0}^{39}$ and hexakis(pyrazol-1-yl)benzene 51, ${ }^{39-42}$ were prepared by nucleophilic substitution of fluorine in 1,2,3,4-tetrafluoro-, 1,2,4,5-tetrafluoro, and hexafluorobenzene, respectively (Figure 4).<smiles>Fc1cc(-n2cccn2)c(F)cc1-n1cccn1</smiles>

46<smiles>c1cnn(-c2cc(-n3cccn3)c(-n3cccn3)cc2-n2cccn2)c1</smiles>

49<smiles>Fc1c(F)c(-n2cccn2)c(F)c(F)c1-n1cccn1</smiles>

47<smiles>Fc1c(-n2cccn2)c(-n2cccn2)c(F)c(-n2cccn2)c1-n1cccn1</smiles>

50<smiles>c1cnn(-c2ccc(-n3cccn3)c(-n3cccn3)c2-n2cccn2)c1</smiles>

48<smiles>c1cnn(-c2c(-n3cccn3)c(-n3cccn3)c(-n3cccn3)c(-n3cccn3)c2-n2cccn2)c1</smiles>

51

\section{Figure 4}

The condensation reaction between terephthalaldehyde 1, dimedone 52 and 4-phenylurazole 53 gave 9,9'-(1,4-phenylene)bis(6,7-dihydro-[1,2,4]triazolo[1,2-a]indazole-trione) 54 (Scheme $14)^{43}$<smiles>CC(OS(=O)(=O)c1ccccc1)C1C(C)(C)CC(=O)CC1(C)C</smiles>

\section{Scheme 14}

\subsection{1,4-Phenylene- bis-imidazoles and their fused derivatives}

The 1,4-bis(1-chloro-2,2-dicyanovinyl)benzene 55 reacts with excess amount of ethylenediamine to give 1,4-bis(4,5-dihydro- $1 H$-imidazol-2-yl)benzene 56 at room temperature (Scheme 15$){ }^{44}$ 


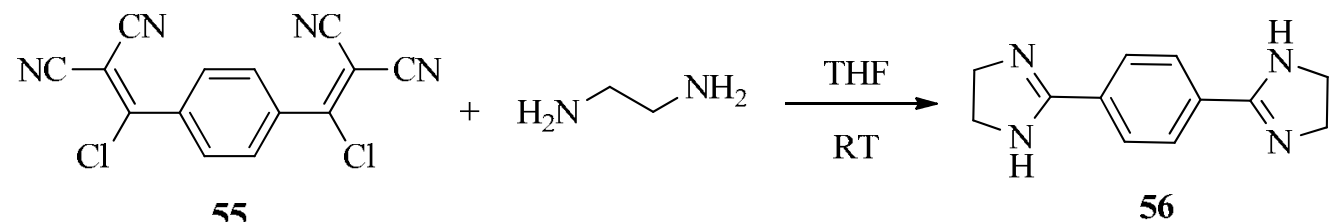

\section{Scheme 15}

Similarly, the condensation of enantiopure 1,2-diamines with terephthalaldehyde (1), in toluene followed by treatment with $\mathrm{N}$-bromosuccinimide in dichloromethane gives direct access to enantiopure 1,4-bis[4,5-diphenyl-4,5-dihydro- $1 H$-imidazol-2-yl]benzene 57 and 1,4-bis[4,5dimesyl-4,5-dihydro-1 $H$-imidazol-2-yl]benzene 58 (Figure 5). ${ }^{45}$<smiles>c1ccc(C2N=C(c3ccc(C4=N[C@@H](c5ccccc5)[Al]N4)cc3)N[C@H]2c2ccccc2)cc1</smiles>



\section{Figure 5}

The 2,2'-(1,4-phenylene)bis( $1 H$-imidazole-5-carboxamide) 63 was prepared by multicomponent reaction of terephthalic acid 59, cyclohexylisocyanide 60, $n$-butylamine 61 and phenylglyoxal hydrate 62 (Scheme 16). ${ }^{46}$

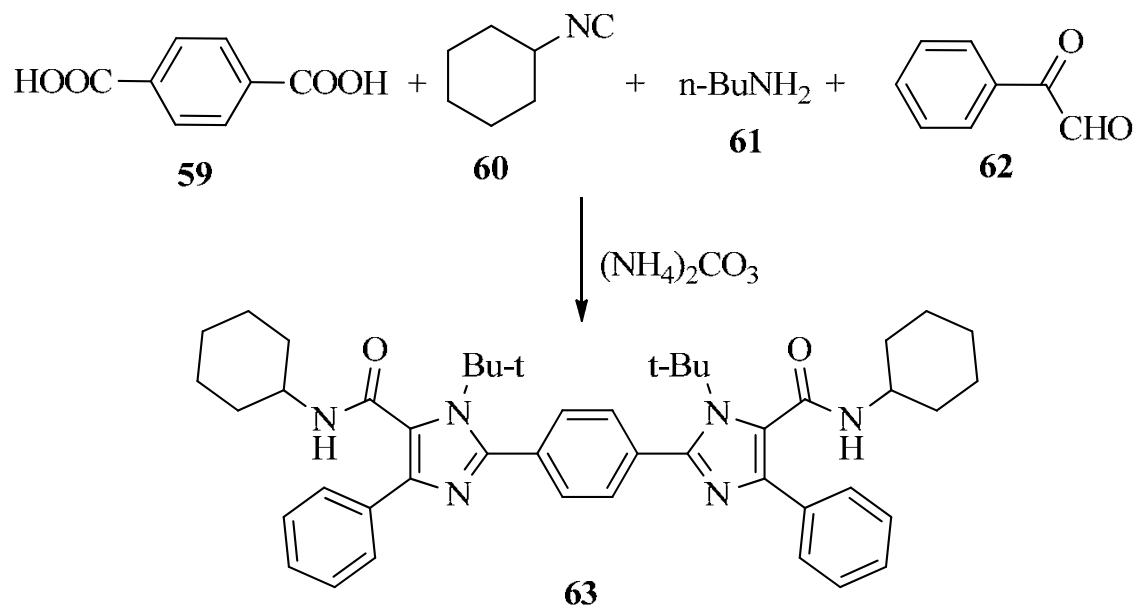

\section{Scheme 16}

The 1,1'-(1,4-phenylene)bis(dihydropyrimidine-2,4(1H,3H)-dione) 65 was also obtained along with 2,2'-(3,3'-(1,4-phenylene)bis(2,5-dioxoimidazolidine-4,3-diyl))diacetic acid $\mathbf{6 6}$ by heating aspartic acid dimer 64 with urea (Figure 6). ${ }^{47}$ 
<smiles>O=C(O)CC(Nc1ccc(NC(CC(=O)O)C(=O)O)cc1)C(=O)O</smiles>

64<smiles>O=C1CCN(c2ccc(N3CCC(=O)NC3=O)cc2)C(=O)N1</smiles>

65<smiles>O=C(O)CC1C(=O)NC(=O)N1c1ccc(N2C(=O)NC(=O)C2CC(=O)O)cc1</smiles>

66

Figure 6

Heating the tetracarboxylic acid $\mathbf{6 4}$ with potassium thiocyanate in acetic acid and subsequent addition of hydrochloric acid gave 2,2'-(3,3'-(1,4-phenylene)bis(5-oxo-2-thioxoimidazolidine4,3-diyl))diacetic acid 67 (Figure 7). ${ }^{47}$<smiles>O=C(O)CC1C(=O)NC(=S)N1c1ccc(N2C(=S)NC(=O)C2CC(=O)O)cc1</smiles>

\section{Figure 7}

Treatment of 4-(benzylidene-4-benzenesulphoate)-2-phenyl-2-oxazolin-5-one 68 with 1,4diaminobenzene 25 in acetic acid containing catalytic amounts of freshly fused sodium acetate gave the corresponding 1,1'-(1,4-phenylene)bis(4-arylidene-2-phenyl-1H-imidazol-5(4H)-one) 69 (Figure 8). ${ }^{48}$<smiles>O=C1OC(c2ccccc2)=N/C1=C\c1ccc(S(=O)(=O)c2ccccc2)cc1</smiles>

68

$$
\mathrm{Ar}=-\mathrm{C}_{6} \mathrm{H}_{4}-\mathrm{SO}_{3}-\mathrm{Ph}
$$<smiles>O=C1C(=C[AlH2])N=C(c2ccccc2)N1c1ccc(N2C(=O)C(=C[AlH2+])N=C2c2ccccc2)cc1</smiles>

69

\section{Figure 8}

When 1,4-phenylenedicarbamothioyl cyanide 70 was reacted with two moles of acetonitrile in tetrahydrofuran containing triethylamine at room temperature cyclization occurred to afford 1,1'-(1,4-phenylene)bis(4-imino-2-methyl-1H-imidazole-5(4H)-thione) 71 (Scheme 17). ${ }^{49}$ 


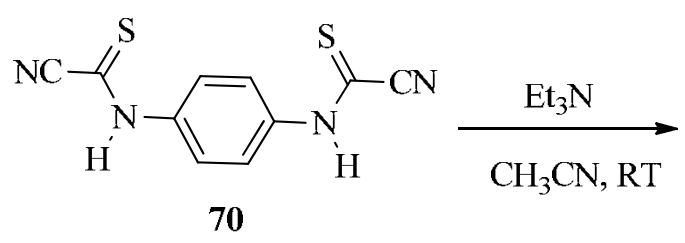<smiles>CC1=NC(=N)C(=S)N1c1ccc(N2C(=S)C(=S)N=C2C)cc1</smiles>

\section{Scheme 17}

Also, the 1,4-phenylenedicarbamothioyl cyanide $\mathbf{7 0}$ underwent cyclization upon its reaction with phenyl iso(thio)cyanate in tetrahydrofuran containing a catalytic amount of triethylamine giving the corresponding 3,3'-(1,4-phenylene)bis(4-thioxoimidazolidin-2-one) 72a and/or 3,3'(1,4-phenylene)bis(imidazolidine-2,4-dithione) 72b, respectively (Scheme 18). ${ }^{49}$

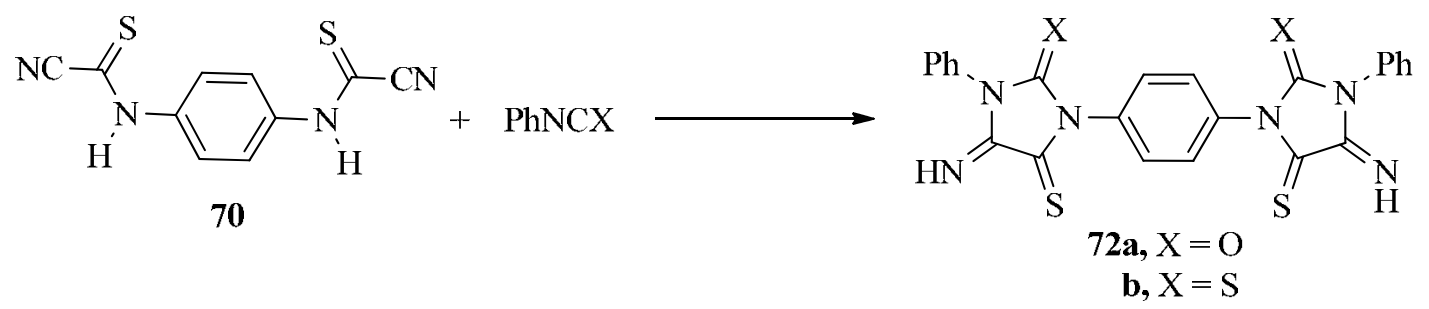

\section{Scheme 18}

Reaction of 72a with $\mathrm{DMF} / \mathrm{HCl}$ and with phenyl hydrazine gave the corresponding 1,1'-(1,4phenylene)bis(5-thioxoimidazolidine-2,4-dione) 73 and 3,3'-(1,4-phenylene)bis(5-imino-1phenyl-4-(2-phenylhydrazono)imidazolidin-2-one) 74 (Figure 9). ${ }^{49}$<smiles>O=C1C(=S)N(c2ccccc2)C(=O)N1c1ccc(N2C(=O)N(c3ccccc3)C(=O)C2=S)cc1</smiles>

73<smiles>N=C1/C(=N\Nc2ccccc2)N(c2ccc(-n3c(=O)n(-c4ccccc4)c(=O)n3-c3ccccc3)cc2)C(=O)N1c1ccccc1</smiles>

74

\section{Figure 9}

Ceric ammonium nitrate (CAN) is used as an efficient catalyst for the synthesis of 1,4bis(4,5-diphenyl-1H-imidazol-2-yl)benzene $\mathbf{7 6}$ via condensation of terphthaldehyde $\mathbf{1}$, benzoin 75, and ammonium acetate (Scheme 19). ${ }^{50}$ 


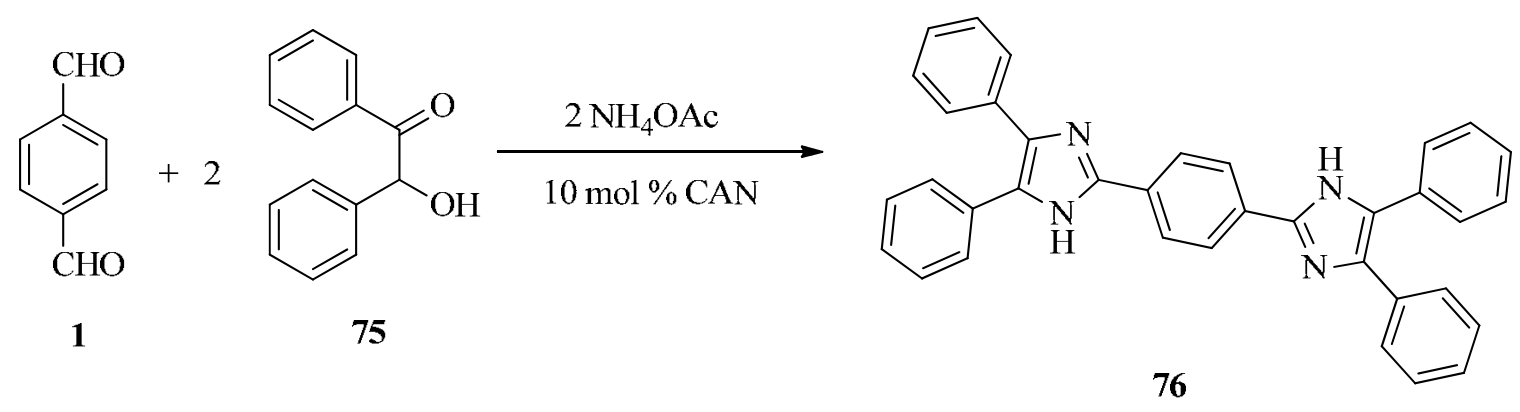

\section{Scheme 19}

The reaction of two moles of 1,2-phenylenediamine derivatives 77 with terphthalaldehyde 1 gave the 1,4-bis $(1 H$-benzo[ $d$ ]imidazol-2-yl)benzene $\mathbf{7 8}$ by PEG-mediated catalyst-free synthesis under solvent-less conditions (Scheme 20). ${ }^{51}$<smiles></smiles>

\section{Scheme 20}

Shaabani et al. $^{52}$ have described the synthesis of 1,4-phenylene-bis(imidazo[1,2-a]pyridines), 1,4-phenylene- bis-pyrimidines, and 1,4-phenylene-bis-pyrazines $\mathbf{8 0}$ by a pseudo-fivecomponent condensation of 2-amino-pyridines or 2-amino-pyrimidines and/or 2-aminopyrazines $\mathbf{7 9}$ with terephthalaldehyde $\mathbf{1}$ and isocyanides $\mathbf{6}$ in the presence of $p$-toluenesulfonic acid in methanol (Scheme 21).

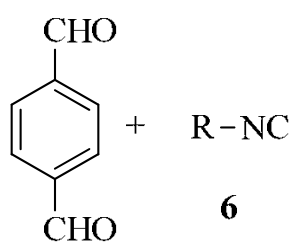

1

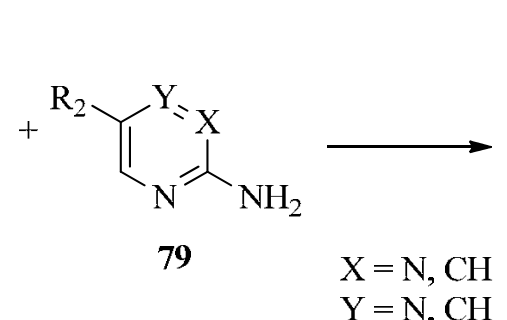

$\mathrm{Y}=\mathrm{N}, \mathrm{CH}$<smiles></smiles>

80

\section{Scheme 21}

\subsection{1,4-Phenylene- bis-oxazoles}

The 1,4-bis(4,5-dihydrooxazol-2-yl)benzene 83 was prepared in two-steps. The dimethylterephthalate $\mathbf{8 1}$ reacted with 2-aminoethanol to give the $N, N^{\prime}$-bis(2-hydroxyethyl)terephthalamide 82. Subsequent treatment with thionyl chloride furnished $\mathbf{8 3}$ (Scheme 22). ${ }^{53,54}$ 
<smiles>COC(=O)c1ccc(C(=O)OC)cc1</smiles>

81<smiles>O=C(NCCO)c1ccc(C(=O)NCCO)cc1</smiles>

82

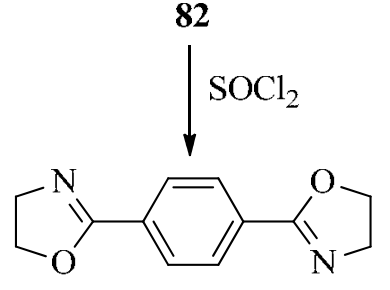

83

\section{Scheme 22}

When 1,4-phenylenedicarbamothioyl cyanide 70 was treated with two moles of acetaldehyde in tetrahydrofuran containing a catalytic amount of triethylamine a product was formed which was formulated as 3,3'-(1,4-phenylene)bis(5-imino-2-methyloxazolidine-4-thione) 84a. Hydrolysis of 84a by $\mathrm{DMF} / \mathrm{HCl}$ gave 3,3'-(1,4-phenylene)bis(4-thioxooxazolidin-5-one) 84b (Scheme 23). ${ }^{49}$<smiles>CC(C)CCCCCC#N</smiles>

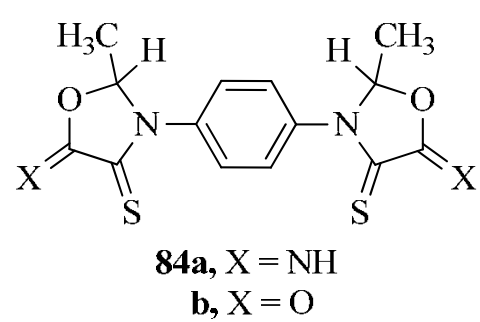

\section{Scheme 23}

\subsection{1,4-Phenylene- bis-isoxazoles}

Shabarov and coworkers ${ }^{55}$ found that under the influence of nitrosyl cation 1,4-dicyclopropylbenzene 85 is converted with high yields into 5-(4-cyclopropylphenyl)-4,5-dihydroisoxazole 86. It should be noted ${ }^{56-58}$ that the second three-carbon ring is not transformed with the initially employed reagent ratio and is, therefore, converted into the 1,4-bis(4,5-dihydroisoxazol-5yl)benzene 87 only with extreme difficulty (Scheme 24).

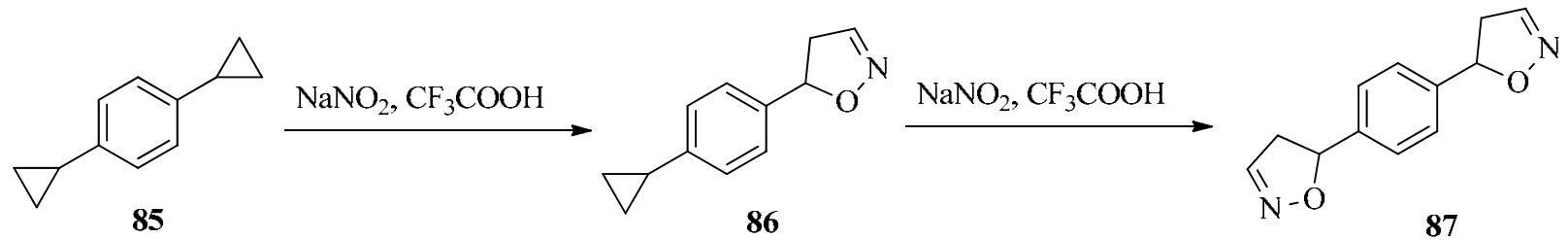

Scheme 24 


\subsection{1,4-Phenylene- bis-thiazoles and their fused derivatives}

Condensation of 1,4-diaminobenzene 25 with arylaldehyde in aqueous ethanol gave the corresponding diarylidenebenzene-1,4-diamine 88, which on condensation with thioglycollic acid furnished 3,3'-(1,4-phenylene)bis(2-aryl-thiazolidin-4-one) 89 (Scheme 25). ${ }^{59,60}$

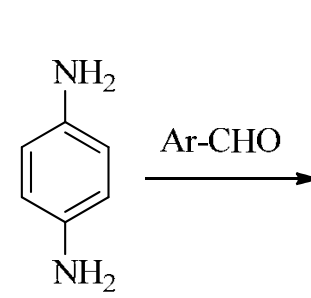

25

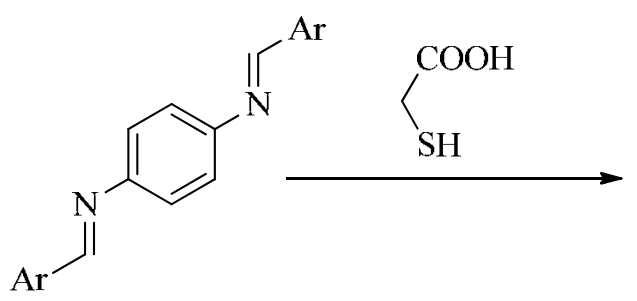

88<smiles>O=C1CSC([Al])N1c1ccc(N2C(=O)CSC2[Al])cc1</smiles>

89

$\mathrm{Ar}=\mathrm{C}_{6} \mathrm{H}_{5}, p-\mathrm{ClC}_{6} \mathrm{H}_{4}, p-\mathrm{OCH}_{3} \mathrm{C}_{6} \mathrm{H}_{4}$

Scheme 25

Condensation of $\mathbf{8 9}$ with arylaldehyde yielded 3,3'-(1,4-phenylene)bis(5-arylidenethiazolidin-4-one) 90, which when treated with 2,4-dinitrophenylhydrazine afforded the cyclized product, 1,4- bis(pyrazolo[3,4- $d]$ thiazol-6(5H)-yl)benzene 91, in one step (Figure 10). ${ }^{60}$

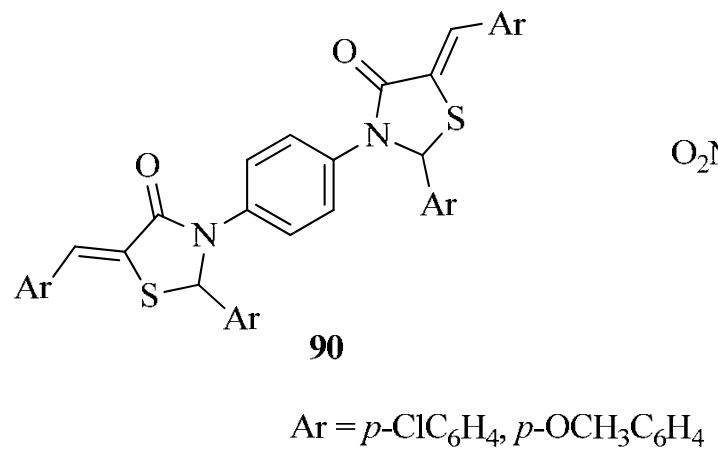<smiles>[Y19]C1SC2C(=NN1c1ccc([N+](=O)[O-])cc1[N+](=O)[O-])N(c1ccc(N3C(=N)C(Nc4ccc([N+](=O)[O-])cc4[N+](=O)[O-])N3C([Al])[Al])cc1)C2[Al]</smiles>

Figure 10

\section{Five-membered Rings with Three Heteroatoms}

\subsection{1,4-Phenylene- bis-triazoles and their fused derivatives}

Shaker et al $^{61}$ reported that the bis-semicarbazide 92 on treatment with $\mathrm{NaOH}$ underwent cyclization to the 3,3'-(1,4-phenylene)bis(1H-1,2,4-triazol-5(4H)-one) 93 (Scheme 26). 


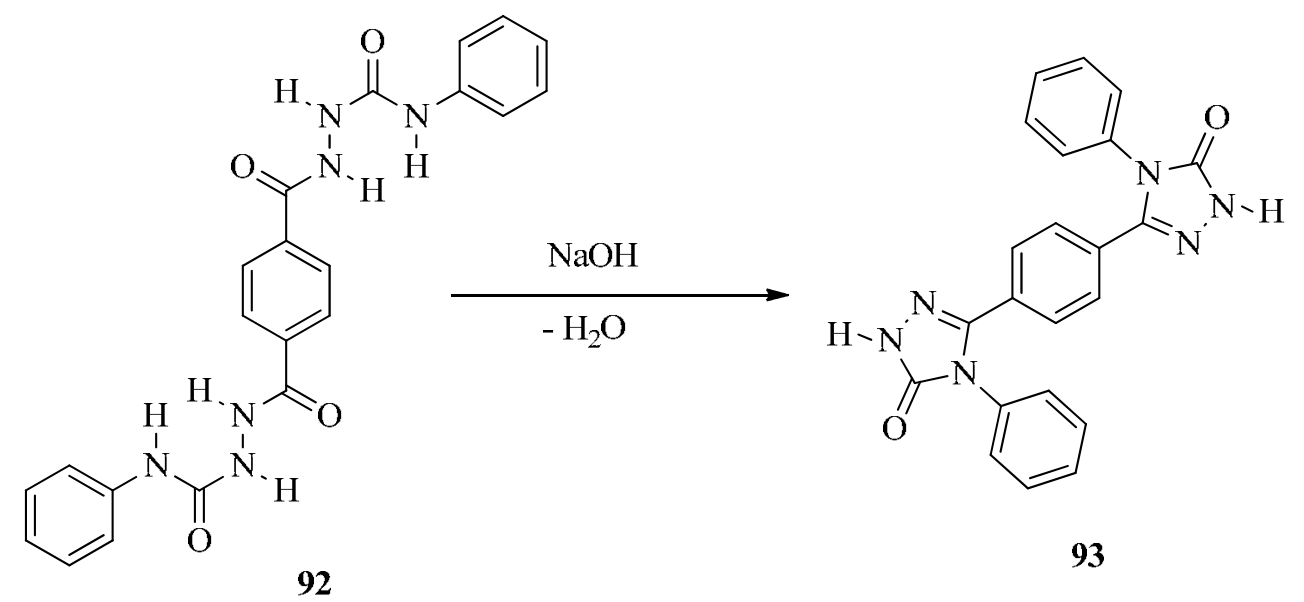

\section{Scheme 26}

Smith et al. ${ }^{62}$ accomplished the reaction of the corresponding dienamines with dimethyl ester tetrazine 94 to yield the corresponding 5,5'-(1,4-phenylene)bis(2H-1,2,3-triazole) 95 and 3,3'(1,4-phenylene)bis(1H-1,2,4-triazole) 96 (Figure 11).

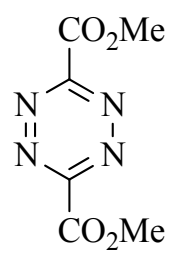

94
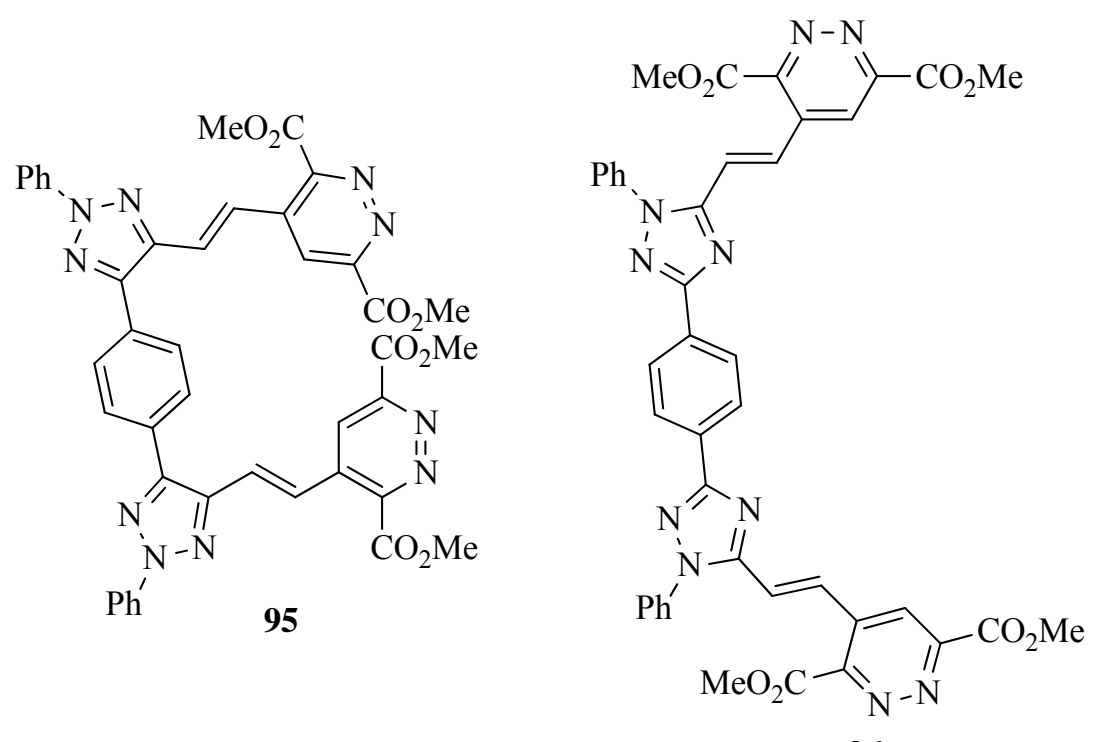

96

\section{Figure 11}

Shaker et al. ${ }^{61}$ reported that the treatment of 1,4-phenylene-bis-thiosemicarbazide 97 with sodium hydroxide gives 3,3'-(1,4-phenylene)bis(1H-1,2,4-triazole-5(4H)-thione) 98 (Scheme 27). 


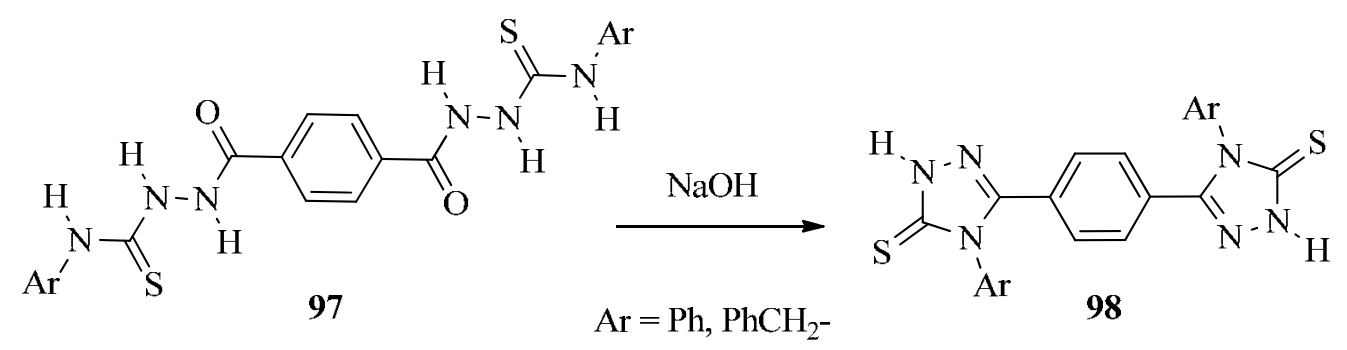

\section{Scheme 27}

The reaction of 98 with ethyl iodide in DMF at room temperature and in the presence of anhydrous potassium carbonate gave 1,4-bis(4H-1,2,4-triazol-3-yl)benzene 99 (Figure 12). ${ }^{61}$

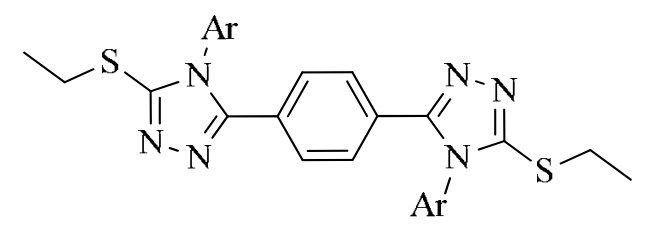

99

\section{Figure 12}

The bis-dithiocarbazinate 101 was synthesized by reacting dihydrazide 100 with carbon disulfide and potassium hydroxide in ethanol. This salt 101 underwent ring closure with an excess of $99 \%$ hydrazine hydrate to give the 5,5'-(1,4-phenylene)bis(4-amino- $4 H$-1,2,4-triazole3-thiol) 102 (Scheme 28). ${ }^{63}$
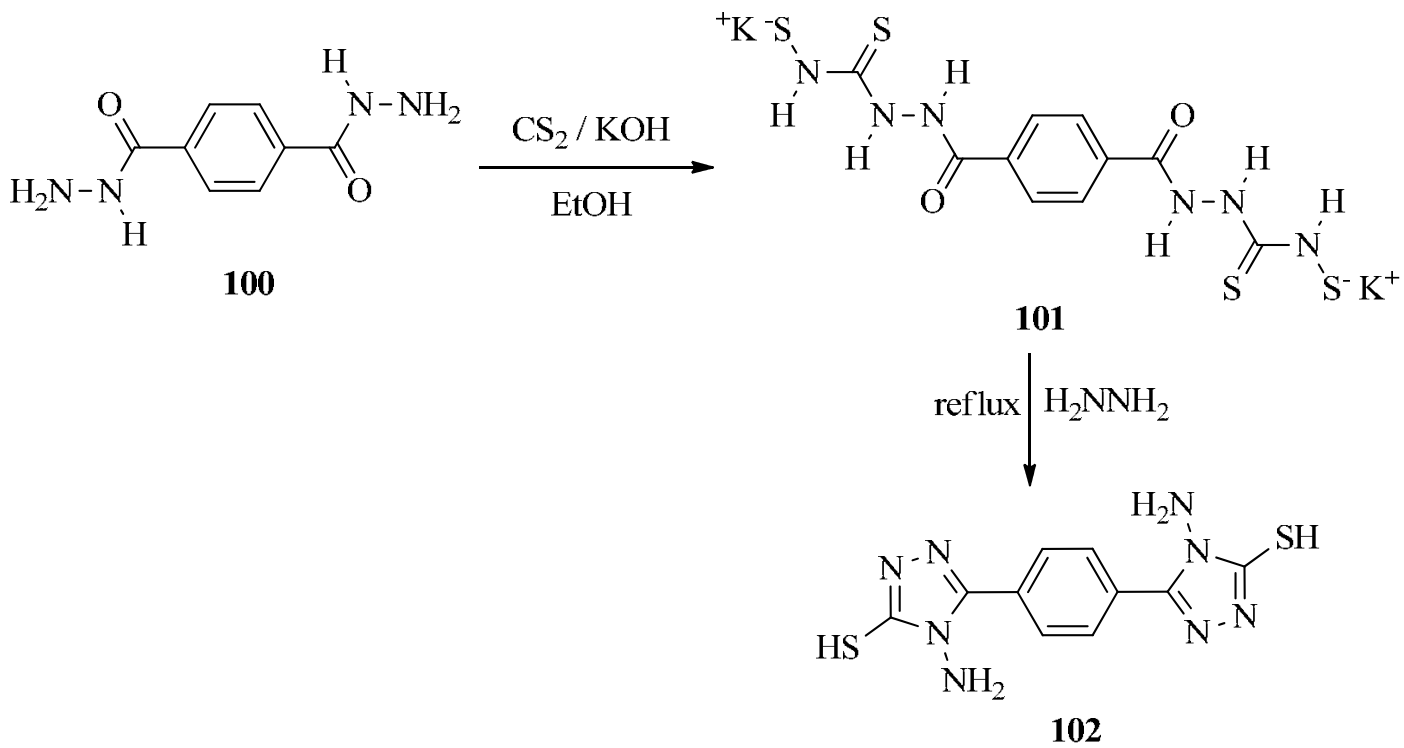

\section{Scheme 28}


The 1,4-bis(4H-1,2,4-triazol-4-yl)benzene 105 was prepared from the reaction of $N, N^{\prime}-(1,4-$ phenylene)bis-2-pyridinecarbothioamide 103 with benzoylhydrazine 104 (Scheme 29). ${ }^{64,65}$
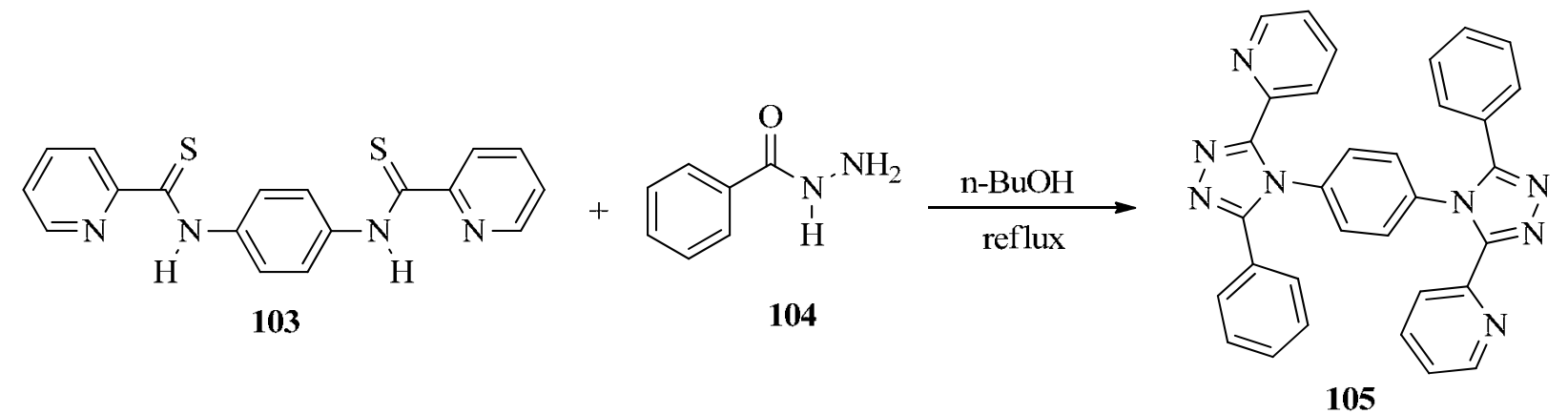

\section{Scheme 29}

When two moles of benzoylhydrazine 104 was reacted with 1,4-phenylenedicarbamothioyl cyanide $\mathbf{7 0}$ the 4,4'-(1,4-phenylene)bis(3-phenyl-1H-1,2,4-triazole-5(4H)-thione) 106 was obtained (Scheme 30$){ }^{49}$
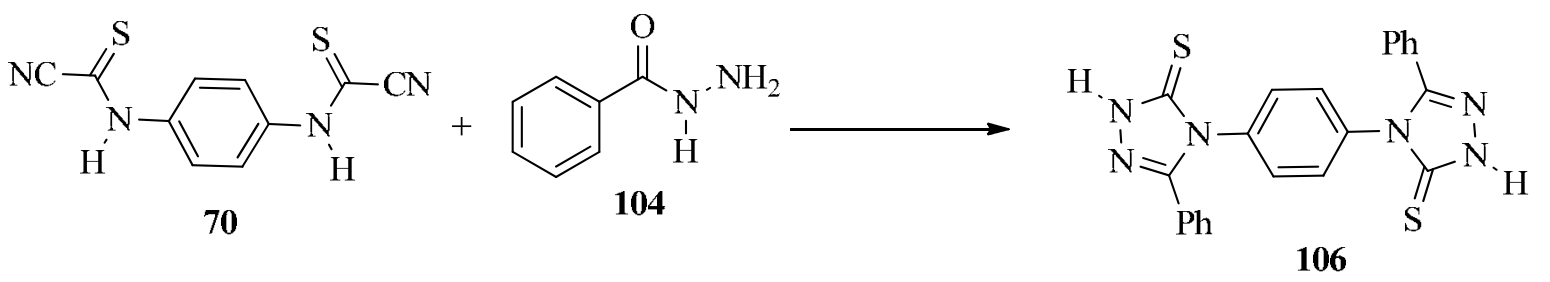

\section{Scheme 30}

The 1,4-phenylene-bis(4-amino-4H-1,2,4-triazole-3-thiol) 102 was converted to 1,4bis(1,2,4]-triazolo[3,4-b][1,3,4]thiadiazol-3-yl)benzene 107a,b in a one pot reaction, by condensation with aromatic acids in the presence of $\mathrm{POCl}_{3}\left(\mathrm{Scheme}_{31)}{ }^{63}\right.$

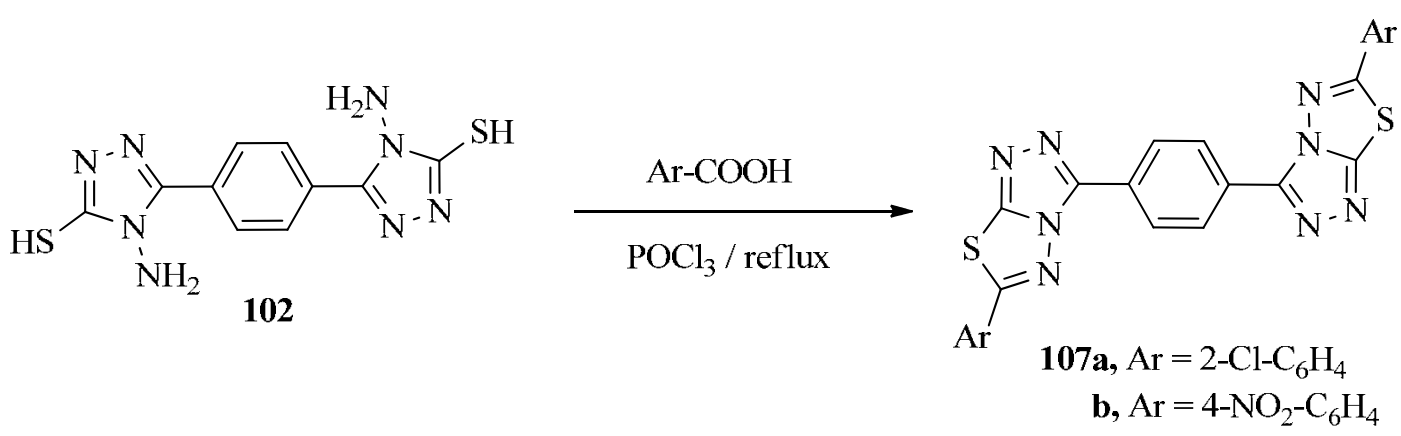

\section{Scheme 31}


The condensation of dihydrazide 100 with phthalic anhydride 108 leads to the formation of 2,2'-(1,4-phenylene)bis(5H-[1,2,4]triazolo[5,1-a]isoindol-5-one) 109 (Scheme 32). ${ }^{66}$<smiles>CC(C)(C)C1C(=O)OC(=O)c2ccccc2C1=O</smiles>

\section{Scheme 32}

The 1,4-bis(pyrazinothienotriazolopyrimidinones)benzene $\mathbf{1 1 1}$ was synthesized by the intermolecular aza-Wittig reaction of phosphazenes 110 with acid chloride $14(\mathrm{R}=\mathrm{H})$ followed by heterocyclization (Scheme 33). ${ }^{67}$<smiles>O=C(Cl)c1ccc(C(=O)Cl)cc1</smiles>

14<smiles>Nc1nc2c(sc3nccnc32)c(=O)n1N=[NH2+]</smiles>

110<smiles>O=c1c2sc3nccnc3c2nc2n([Al])c(-c3ccc(-c4nn5c(=O)c6sc7nccnc7c6nc5n4[Al])cc3)nn12</smiles>

111

\section{Scheme 33}

The reaction with 1,4-phenylene diisocyanate $\mathbf{1 1 2}$ and two equivalents of the phosphorimidate 113 led to the formation of 1,4-bis(imidazo[4,5-d][1,2,3]triazol-2(4H)yl)benzene 114 (Scheme 34). ${ }^{68}$<smiles>O=C=Nc1ccc(NC(=O)[O-])cc1</smiles>

112<smiles>CCOP(=O)(O)Nc1c([N+](=O)[O-])nc(C)n1CC</smiles>

113<smiles>CCn1c(C)nc2nn(-c3ccc(-n4nc5nc(C)n(CC)c5n4)cc3)nc21</smiles>

114

\section{Scheme 34}

\subsection{1,4-Phenylene- bis-dioxazoles}

Cyclization of benzene-1,4-dicarbaldehyde dioxime 115 with different aromatic aldehydes in inert atmosphere yielded 1,4-bis(1,4,2-dioxazol-3-yl)benzene 116 (Scheme 35). ${ }^{20}$ 


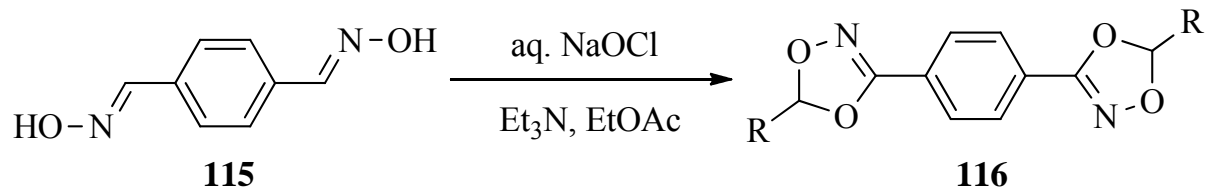

\section{Scheme 35}

\subsection{1,4-Phenylene- bis-oxadiazoles}

The condensation of dihydrazide $\mathbf{1 0 0}$ with aromatic aldehydes afforded corresponding hydrazones 117, respectively. Cyclization of 117 with propionic anhydride at $160{ }^{\circ} \mathrm{C}$ yielded $1,4-$ bis[3- $N$-propionyl-2-aryl-1,3,4-oxadiazo-5-yl]benzene 118 (Scheme 36) ${ }^{69}$

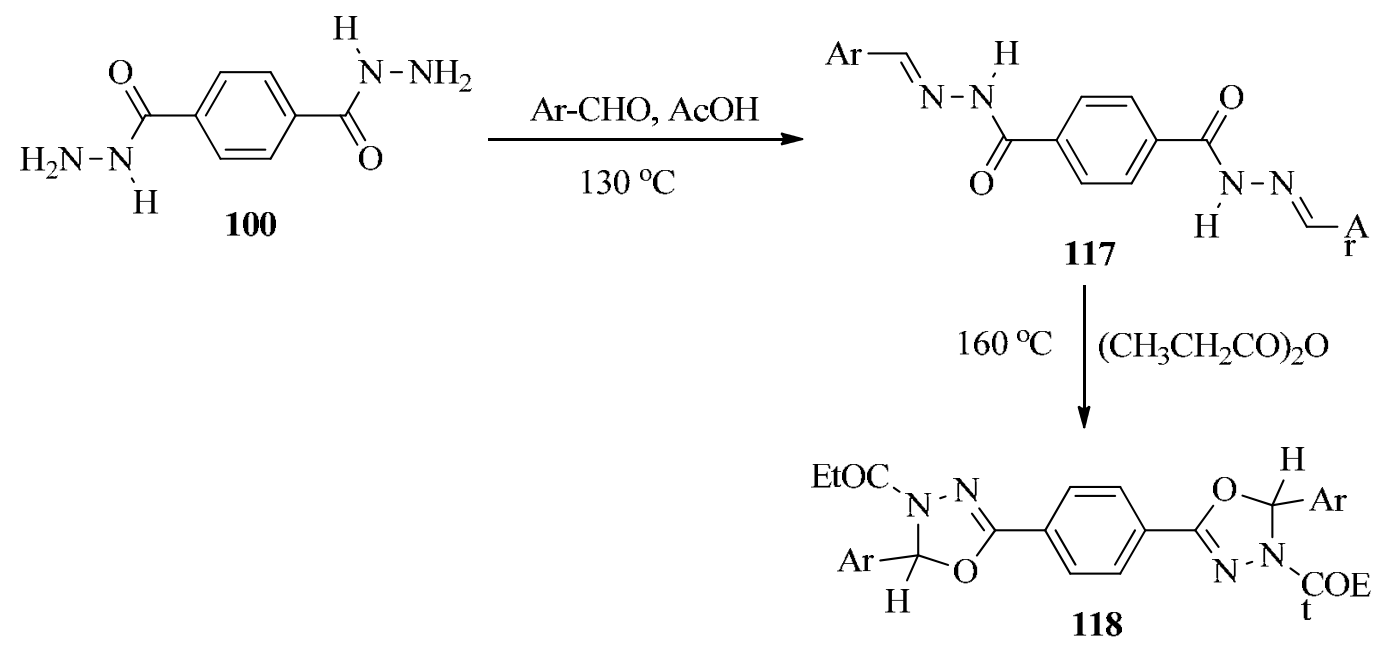

\section{Scheme 36}

Various 1,4-bis(5-aryl-1,3,4-oxadiazol-2-yl)benzene 119 were prepared by treatment of dihydrazide 100 with aromatic acids in the presence of trifluoroacetic acid (Scheme 37) ${ }^{63}$

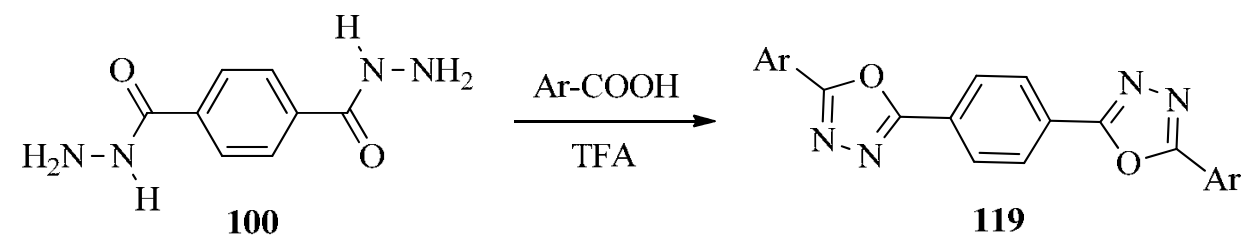

\section{Scheme 37}

The synthesis, optical properties and electrochemical properties, of 1,4-bis(5-p-tolyl-1,3,4oxadiazol-2-yl)benzene 121 are reported (Scheme 38). ${ }^{70}$ 
<smiles>Cc1ccc(C(=O)NNC(=O)c2ccc(C(=O)NN(C)C(=O)NC(=O)c3ccc(C)cc3)cc2)cc1</smiles><smiles>Cc1ccc(-c2nnc(-c3ccc(-c4nnc(-c5ccc(C)cc5)o4)cc3)o2)cc1</smiles>

\section{Scheme 38}

The $N^{1}{ }^{1}, N^{4}$-bis(4-bromo-2,5-bis(octyloxy)benzoyl)terephthalohydrazide 123 was obtained from the reaction of acid chloride $14(\mathrm{R}=\mathrm{H})$ with 4-bromo-2,5-bis(octyloxy)benzohydrazide 122. After cyclodehydration of compound 123, the 1,4-bis(1,3,4-oxadiazol-2-yl)benzene 124 was obtained (Scheme 39). ${ }^{71}$<smiles>O=C(Cl)C1C=[C+]C(=C(Cl)Cl)C=C1</smiles>

14<smiles>CCCCOc1cc(Br)c(OCCC)cc1C(N)=O</smiles>

122

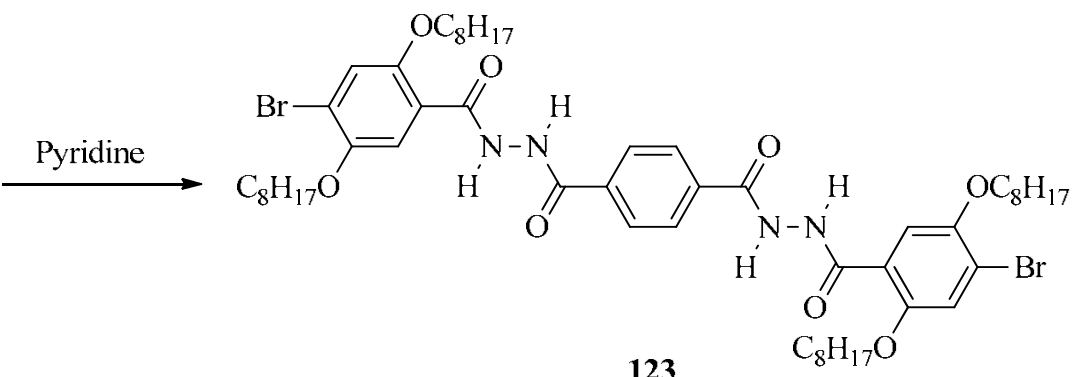

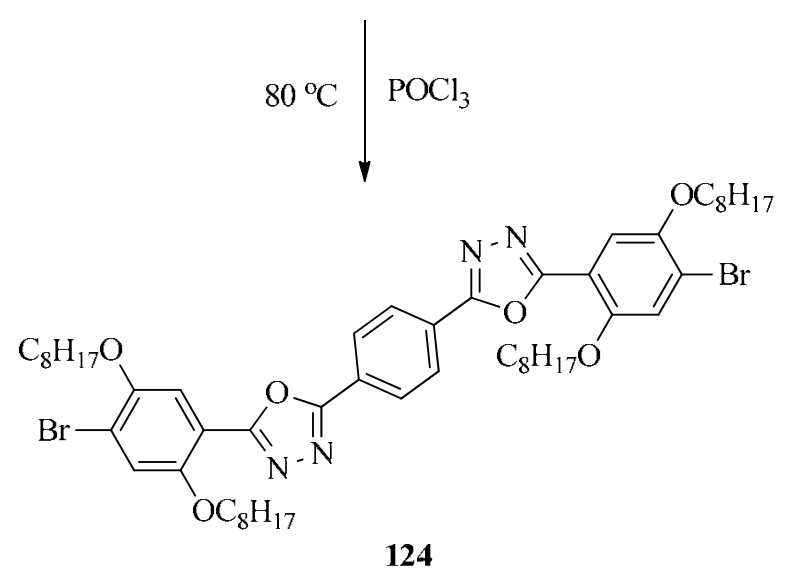

\section{Scheme 39}


Shaker et al. ${ }^{61}$ reported that the bis-semicarbazide 92 on treatment with $\mathrm{NaOH}$ underwent cyclization to the corresponding 5,5'-(1,4-phenylene)bis(1,3,4-oxadiazol) 125 (Scheme 40).<smiles>O=C(NNC(=O)Nc1ccccc1)NNC(=O)Nc1ccccc1</smiles><smiles>c1ccc(Nc2nnc(-c3ccc(-c4nnc(Nc5ccccc5)o4)cc3)o2)cc1</smiles>

\section{Scheme 40}

\subsection{1,4-Phenylene- bis-thiadiazoles}

Shaker et al. ${ }^{61}$ reported that 1,4-phenylene-bis-thiosemicarbazide 97 reacted with phosphoryl chloride at reflux to give 5,5'-(1,4-phenylene)bis(1,3,4-thiadiazol) 126 (Scheme 41).<smiles>O=C(NNC(=S)Nc1ccccc1)c1ccc(C(=O)NNC(=S)Nc2ccccc2)cc1</smiles>

\section{Scheme 41}

\section{Five-membered Rings with Four Heteroatoms}

\subsection{1,4-Phenylene-bis-tetrazoles}

A series of 1,4-bis(tetrazole)benzene derivatives 127 - 130 were prepared by different methods (Figure 13). ${ }^{72-74}$<smiles></smiles>

127<smiles>[R]n1nnnc1-c1ccc(-c2nnnn2[R])cc1</smiles>

128<smiles>[R]n1nnc(-c2ccc(-c3nnn([R])n3)cc2)n1</smiles>

129

130

\section{Figure 13}




\section{Six-membered Rings with One Heteroatom}

\subsection{1,4-Phenylene- bis-pyrans and their fused derivatives}

The reaction of phenylthioacetone 131 with malononitrile in a molar ratio of 1:2 carried out in absolute ethanol and catalyzed by piperidine afforded 4,4'-(1,4-phenylene)bis(2-amino-6-methyl5-(phenylthio)-4H-pyran-3-carbonitrile) 132 (Scheme 42). ${ }^{75}$<smiles>CC(=O)/C(=C\c1ccc(CC([Pb])C(C)=O)cc1)Cc1ccccc1</smiles>

\section{Scheme 42}

The 4,4'-(1,4-phenylene)bis(7,8-dihydro-4H-chromen-5(6H)-one) derivatives 133 were prepared from terephthalaldehyde 1, dimedone 52 and malononitrile or ethyl cyanoacetate under MW irradiation (Scheme 43). ${ }^{76}$

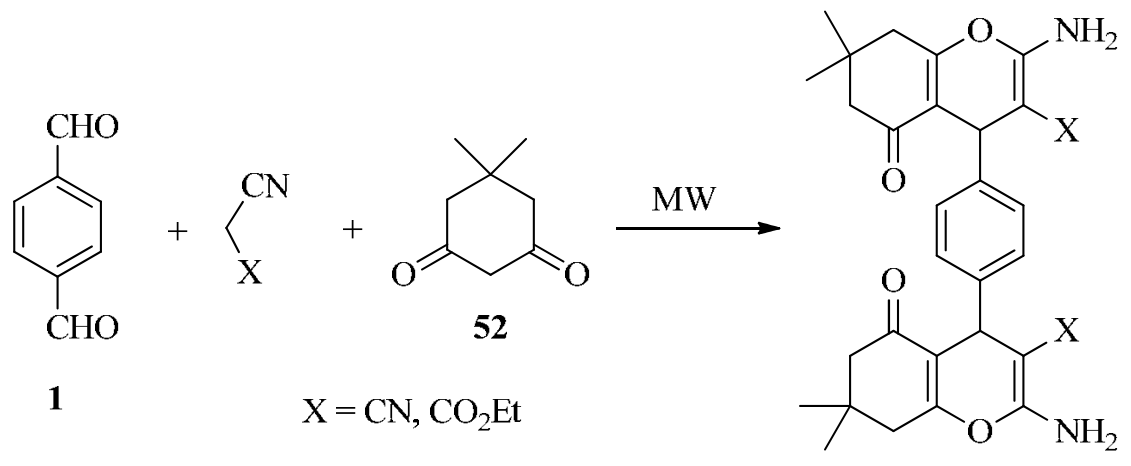

133

\section{Scheme 43}

The multi-component approach to the synthesis of 4,4'-(1,4-phenylene)bis(7,7-dimethyl3,4,7,8-tetrahydro-2 $H$-chromene-2,5(6H)-dione) $\mathbf{1 3 5}$ is based on the reaction of terephthalaldehyde 1, dimedone 52 and Meldrum's acid 134 under MW irradiation (Scheme 44). ${ }^{76}$ 


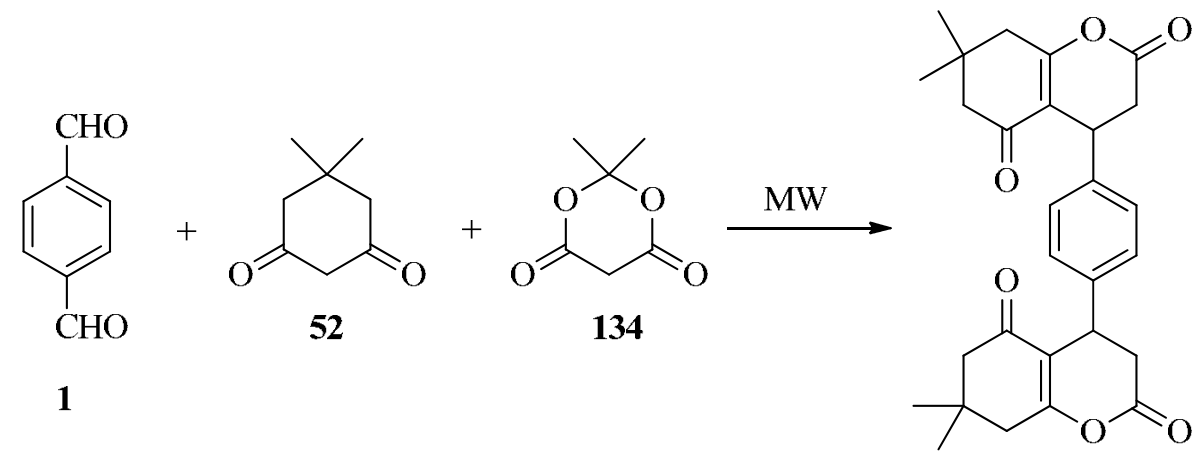

135

\section{Scheme 44}

Reaction of terephthalaldehyde 1, 3-methyl-2-pyrazolin-5-one 136 and malononitrile or methyl cyanoacetate under classical heating ${ }^{77}$ or MW irradiation ${ }^{76}$ gave the corresponding 4,4'(1,4-phenylene)bis(1,4-dihydropyrano[2,3-c]pyrazole) 137 (Scheme 45).

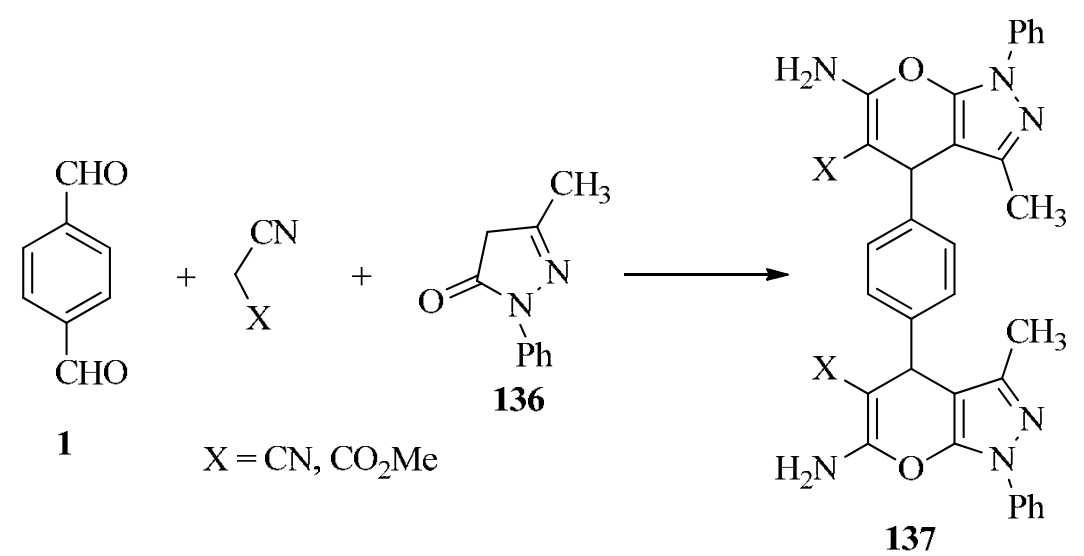

\section{Scheme 45}

Terephthalaldehyde 1, on treatment with malononitrile and some phenolic compounds afforded 138-140 (Figure 14). ${ }^{77}$<smiles>N#CC1=C(N)Oc2ccccc2C1c1ccc(C2C(C#N)=C(N)Oc3ccccc32)cc1</smiles>

138<smiles>N#CC1=C(N)Oc2ccc3ccccc3c2C1c1ccc(C2C(C#N)=C(N)Oc3ccc4ccccc4c32)cc1</smiles>

139<smiles>N#CC1=C(N)Oc2nc(S)ncc2C1c1ccc(C2C(C#N)=C(N)Oc3nc(S)ncc32)cc1</smiles>

140

Figure 14 
The 9,9'-(1,4-phenylene)bis(3,3,6,6-tetramethyl-3,4,5,6,7,9-hexahydro- $1 H$-xanthene1,8(2H)-dione) 141 was prepared by condensing terephthalaldehyde $\mathbf{1}$ with dimedone 52 under different conditions (Figure 15). ${ }^{76,78,79}$

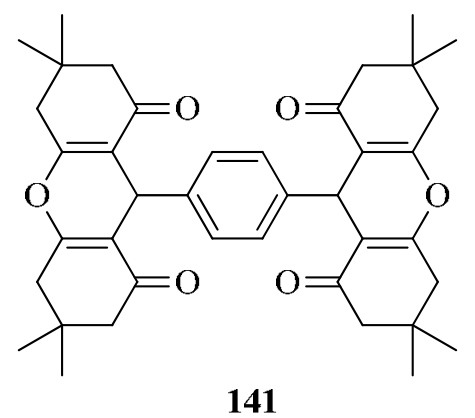

\section{Figure 15}

The 4,4'-(1,4-phenylene)bis(4,5-dihydropyrano[3,2-c]chromene) 143 has been synthesized via a one-pot multi-component condensation of terephthalaldehyde 1 with malononitrile and 4hydroxy-coumarin 142 (Scheme 46). ${ }^{80}$<smiles>O=Cc1ccc(C=O)cc1</smiles>

1<smiles>O=c1cc(O)c2ccccc2o1</smiles>

142
MW<smiles>N#CC1=C(N)Oc2c(c(=O)oc3ccccc23)C1c1ccc(C2C(C#N)=C(N)Oc3c2c(=O)oc2ccccc32)cc1</smiles>

\section{Scheme 46}

\subsection{1,4-Phenylene- bis-thiopyrans}

The 4,4'-(1,4-phenylene)bis(4H-thiopyran) 144 was synthesized by condensation of terephthalaldehyde $\mathbf{1}$, malononitrile and cyanothioacetamide in a 1:2:2 molar ratio (Figure 16). ${ }^{77}$<smiles>N#CC1=C(N)SC(N)=C(C#N)C1c1ccc(C2C(C#N)=C(N)SC(N)=C2C#N)cc1</smiles>

\section{Figure 16}




\subsection{1,4-Phenylene- bis-pyridines and their fused derivatives}

The multi-component approach to the synthesis of diethyl 4,4'-(1,4-phenylene)bis(2-methyl-6oxo-1,4,5,6-tetrahydropyridine-3-carboxylate) $\mathbf{1 4 5}$ is based on the reaction of terephthalaldehyde 1, ethyl acetoacetate, Meldrum's acid $\mathbf{1 3 4}$ and ammonium acetate under MW irradiation (Scheme 47). ${ }^{81}$<smiles>CCOC(=O)C1=C(C)NC(=O)CC1c1ccc(C2CC(=O)NC(C)=C2C(=O)OCC)cc1</smiles>

\section{Scheme 47}

The reaction of terephthalaldehyde $\mathbf{1}$, methyl acetoacetate, and ammonium acetate under MW irradiation in a 1:4:3 molar ratio gave 4,4'-(1,4-phenylene)bis(1,4-dihydropyridine) 146 (Figure 17). ${ }^{81}$<smiles>CC(=O)C1=C(C)NC(C)=C(C(C)=O)C1c1ccc(-c2c(C(C)=O)[nH+]c(C)c(C(C)=O)c2C)cc1</smiles>

\section{Figure 17}

Refluxing an ethanolic solution of terephthalaldehyde 1, malononitrile and cyanothioacetamide in 1:2:2 molar ratio afforded 4,4'-(1,4-phenylene)bis(2,6-diamino-1,4dihydropyridine-3,5-dicarbonitrile) 147 (Figure 18). ${ }^{77}$ 


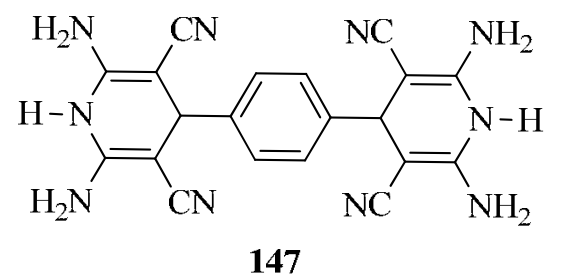

\section{Figure 18}

The multi-component approach to the synthesis of 4,4'-(1,4-phenylene)bis $(3,4,7,8$ tetrahydroquinoline-2,5(1H,6H)-dione) $\mathbf{1 4 8}$ is based on the reaction of terephthalaldehyde $\mathbf{1}$, dimedone 52, Meldrum's acid 134 and ammonium acetate in a 1:2:2:3 molar ratio under MW irradiation (Scheme 48). ${ }^{81}$

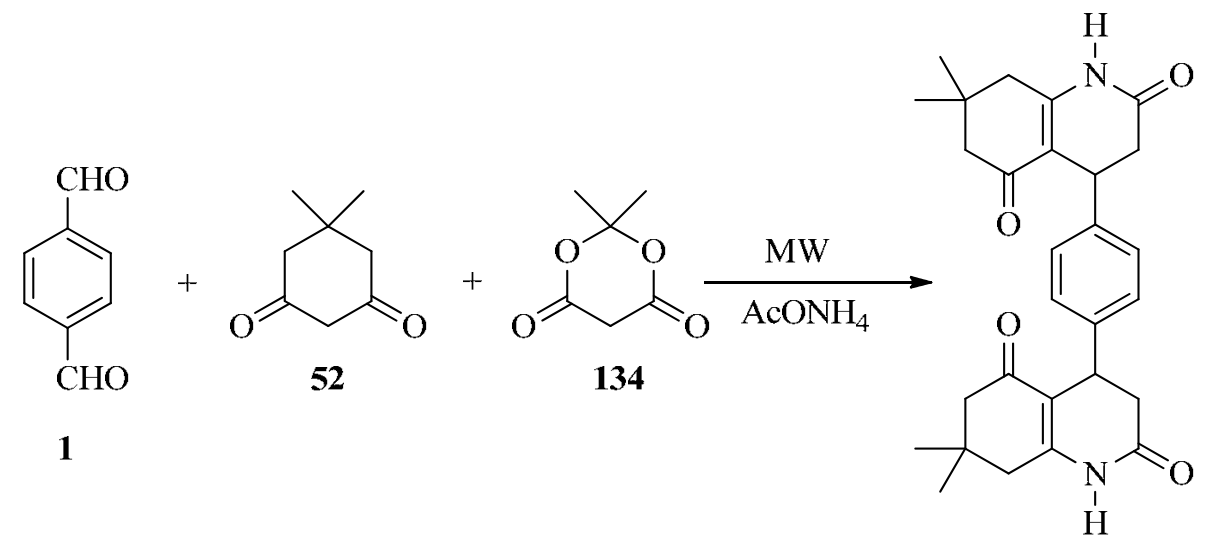

148

\section{Scheme 48}

The 4,4'-(1,4-phenylene)bis(1,4,5,6,7,8-hexahydroquinoline) $\mathbf{1 4 9}$ was prepared from terephthalaldehyde 1, dimedone 52, ethyl acetoacetate and ammonium acetate in a 1:2:2:3 molar ratio under MW irradiation (Scheme 49). ${ }^{81}$<smiles>CCOC(=O)C1=C(C)NC2=C(C(=O)CC(C)(C)C2)C1c1ccc(C2C(C(=O)OCC)=C(C)NC3=C2C(=O)CC(C)(C)C3)cc1</smiles>

\section{Scheme 49}


The boronation of 2,5-bis(2-(tert-butyldimethylsilyloxy)ethyl)-1,4-benzenedibromide 150 gives the corresponding diboronic acid bis(pinacol) ester 151. Head-to-head 6,6'-(2,5-bis(2-(tertbutyldimethylsilyloxy)ethyl)-1,4-phenylene)bis(3-bromopyridine) 153 was synthesized by regioselective Suzuki coupling of 151 with 2,5-dibromopyridine 152 in 58\% yield (Scheme $50)^{82}$

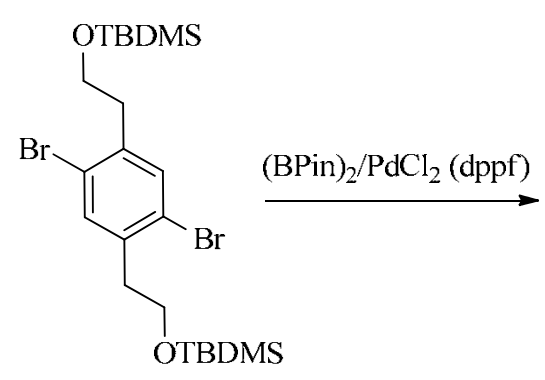

150

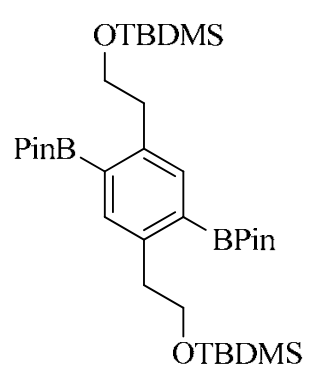

151
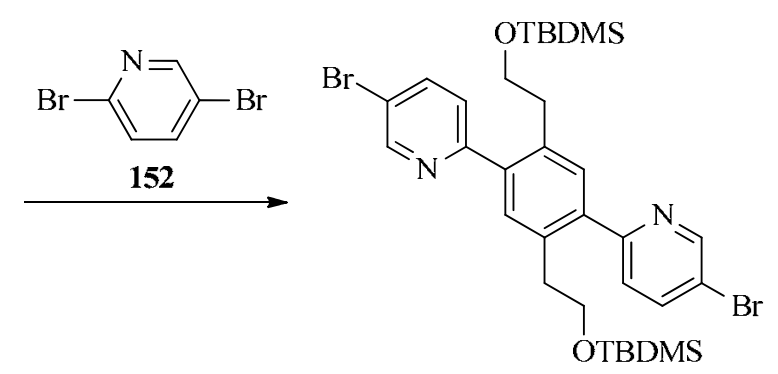

153

\section{Scheme 50}

The 1,4-bis(terpyridine)benzene $\mathbf{1 5 4 ^ { 8 3 }}$ and $\mathbf{1 5 5 ^ { 8 4 }}$ were synthesized by condensation of terephthalaldehyde 1 with a fourfold excess of 4- and/or 2-acetylpyridine in the presence of ammonium acetate in acetic acid (grinding method) ${ }^{83}$ and/or under the action of a base in polyethylene glycol (PEG-300) ${ }^{84}$ at $0{ }^{\circ} \mathrm{C}$ (Figure 19).

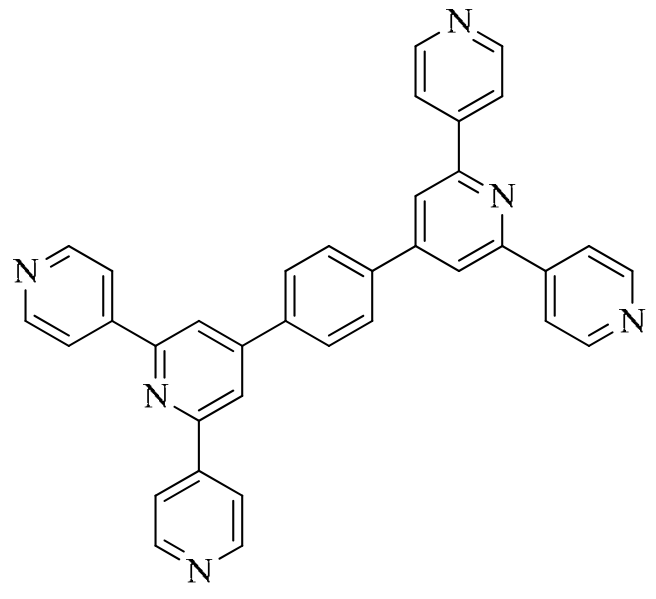

154<smiles>c1ccc(-c2cc(-c3ccc(-c4cc(-c5ccccn5)nc(-c5ccccn5)c4)cc3)cc(-c3ccccn3)n2)nc1</smiles>

155

\section{Figure 19}

Shaker et al. ${ }^{85}$ have been reported a synthetic route to 1,4-bis(4-pyridyl)benzenes 156 via the reaction of terephthalaldehyde ) with two equivalents of malononitrile and acetylhetarenes in the presence of ammonium acetate (Scheme 51). 


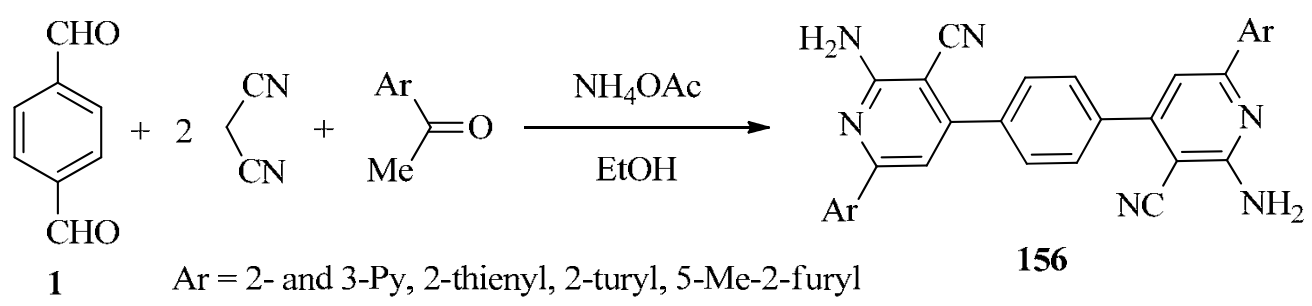

\section{Scheme 51}

The reaction of terephthalaldehyde 1 with $\beta$-amino- $\beta$-(pyrid-4-yl)acrylonitrile 157 in a $4: 1$ molar ratio carried out in $\mathrm{AcOH}$ afforded the desired 4,4'-(1,4-phenylene)bis(pyridine) 158 (Scheme 52). ${ }^{86}$<smiles>O=CC1=C[C+]=CC=C1C=O</smiles>

1<smiles>N#C/C=C(\N)c1ccncc1</smiles>

157<smiles>N#Cc1c(-c2ccncc2)nc(-c2ccncc2)c(C#N)c1-c1ccc(-c2c(C#N)c(-c3ccncc3)nc(-c3ccncc3)c2C#N)cc1</smiles>

158

\section{Scheme 52}

The reaction of dienaminone 159 with malononitrile or ethyl cyanoacetate at ambient temperature in ethanolic solution and in the presence of piperidine afforded the corresponding 6,6'-(1,4-phenylene)bis(pyridin-2(1H)-one) derivatives 160 (Scheme 53). ${ }^{87}$<smiles>[X][X]C(=O)OCC</smiles>

\section{Scheme 53}


Treatment of terephthalaldehyde 1 with malononitrile and cycloalkanones $\mathbf{1 6 1}$ in ethanol containing a catalytic amount of ammonium acetate afforded 4,4'-(1,4-phenylene)bis( $5 H$ cycloalkan $[b]$ pyridine) 162 (Scheme 54). ${ }^{85}$

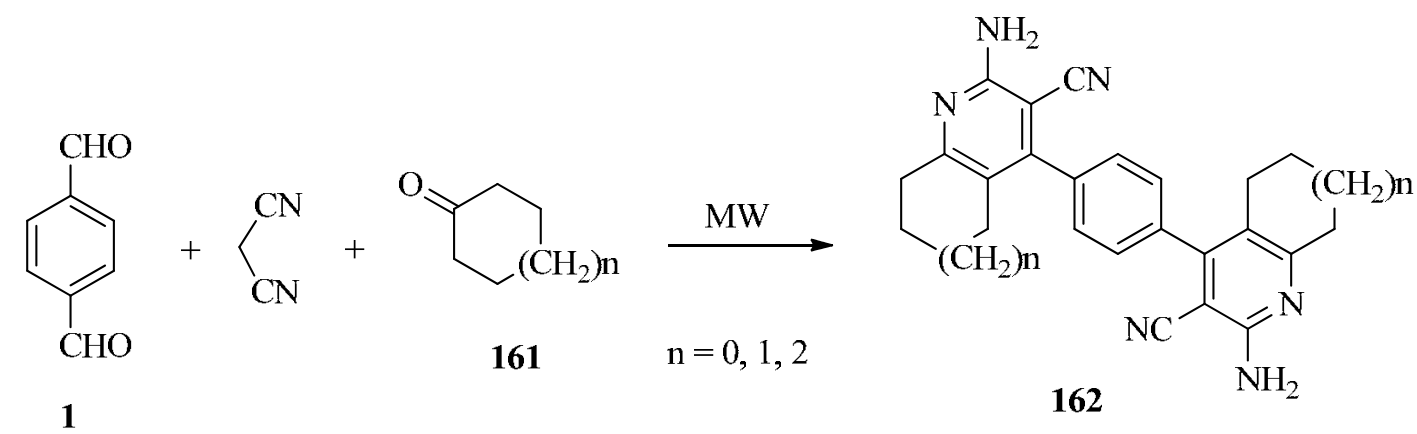

\section{Scheme 54}

The ternary condensation of terephthalaldehyde 1, malononitrile and cyclohexanone in refluxing alcoholic sodium ethoxide gave 4,4'-(1,4-phenylene)bis(5,6,7,8-tetrahydroquinoline) 163 (Figure 20). ${ }^{85}$<smiles>CCOc1nc2c(c(-c3ccc(-c4c(C#N)c(OCC)nc5c4CCCC5)cc3)c1C#N)CCCC2</smiles>

\section{Figure 20}

The aminoaldehyde 164 undergoes double Friedländer condensation with 1,4diacetylbenzene 165 under basic conditions to provide 7,7'-(1,4-phenylene)bis(1,8naphthyridine) 166 (Scheme 55). ${ }^{88}$ 
<smiles>CCOc1nc(N)c(C=O)c(-c2ccccc2)c1C#N</smiles>

164<smiles>CC(=O)c1ccc(C(C)=O)cc1</smiles>

165<smiles>CCOc1nc2nc(-c3ccc(-c4ccc5c(-c6ccccc6)c(C#N)c(OCC)nc5n4)cc3)ccc2c(-c2ccccc2)c1C#N</smiles>

166

\section{Scheme 55}

The condensation of terephthalaldehyde 1, with malononitrile and 6-amino-2-thiouracil 167 in ethanol containing in the presence of piperidine afforded the corresponding 5,5'-(1,4phenylene)bis(1,2,3,4-tetrahydropyrido[2,3- $d]$ pyrimidine) 168 (Scheme 56). ${ }^{89}$

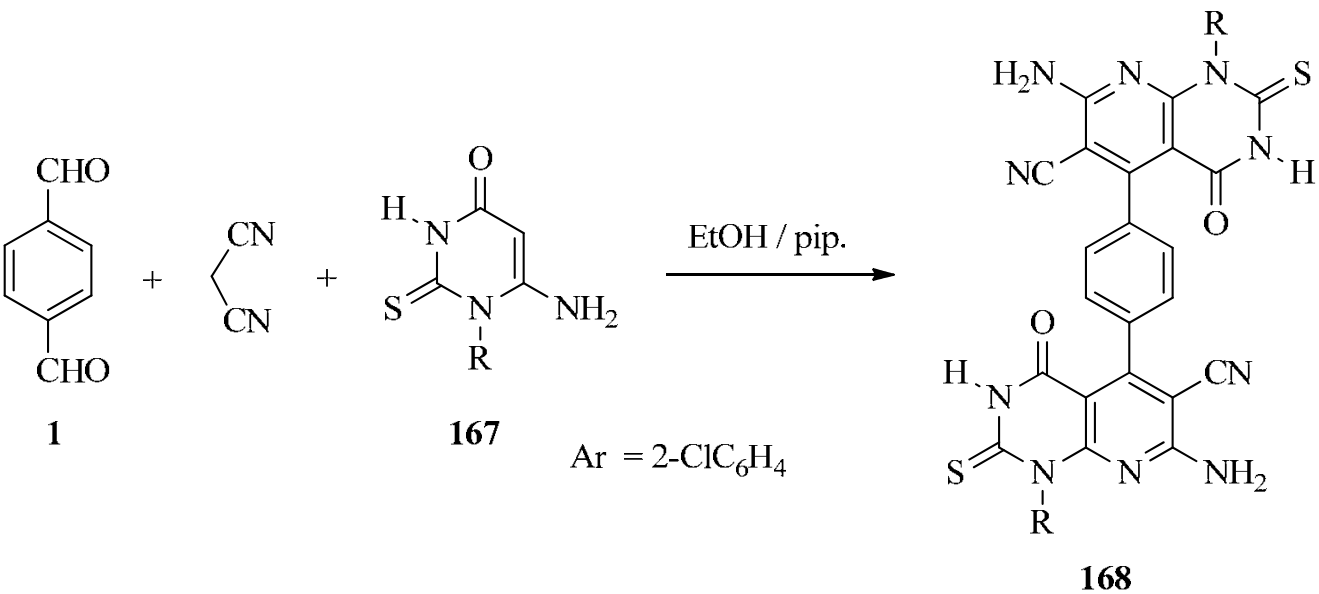

\section{Scheme 56}

Similarly, 5,5'-(1,4-phenylene)bis(2,3-dihydropyrido[2,3- $d$ ]pyrimidin-4(1H)-one) derivatives 169 were synthesized by treatment of 6-amino-2-thiouracil $167 \quad\left(\mathrm{R}=2-\mathrm{ClC}_{6} \mathrm{H}_{4}\right)$ with terephthalaldehyde $\mathbf{1}$ and acetylhetarenes (Figure 21). ${ }^{89}$<smiles>CCc1cc(-c2ccc(-c3cc(CC)nc4c3c(=O)[nH]c(=S)n4-c3ccccc3Cl)cc2)c2c(=O)[nH]c(=S)n(-c3ccccc3Cl)c2n1</smiles>

Figure 21

169, Het = 3-pyridyl, 2-thienyl, 5-methyl-2-furyl 
The 9,9'-(1,4-phenylene)bis(3,3,6,6-tetramethyl-3,4,6,7,9,10-hexahydroacridine-1,8(2H,5H)dione) $170(\mathrm{R}=\mathrm{H})$ has been synthesized by condensation of terephthalaldehyde with dimedone in the presence of ammonium acetate under MW irradiation. ${ }^{78,81}$ The $N$-hydroxyacridine $\mathbf{1 7 0}^{78,90}$ $(\mathrm{R}=\mathrm{OH})$ has been synthesized by using hydroxylamine instead of ammonium acetate (Figure 22).



$170(\mathrm{R}=\mathrm{H}, \mathrm{OH})$

\section{Figure 22}

In 1999, it was reported that the reaction between benzyne 171 and diarylidenebenzene-1,4diamine 88 led to 1,4-bis(acridin-9-yl)benzene 172 via [2+2] cycloadditions (Scheme 57). ${ }^{91}$

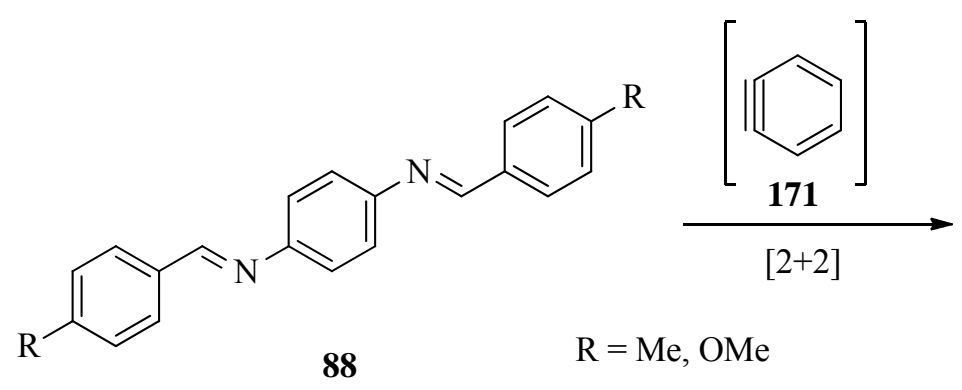

88
Me, OMe<smiles>[R]c1ccc2nc3ccccc3c(-c3ccc(-c4c5ccccc5nc5ccc([R])cc45)cc3)c2c1</smiles>

172

\section{Scheme 57}

The 1,4-bis(1,2,3,4,5,6,7,8-octahydroacridin-10(9H)-yl)benzene $\mathbf{1 7 3}$ was synthesized from methylene-2,2'-dicyclohexanone and 1,4-diaminobenzene 25 (Figure 23). ${ }^{92}$

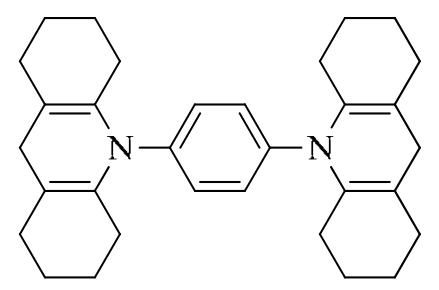

173

\section{Figure 23}




\section{Six-membered Rings with Two Heteroatoms}

\subsection{1,4-Phenylene- bis-pyrimidines and their fused derivatives}

The 4,4'-(1,4-phenylene)bis(3,4-dihydropyrimidine) $\mathbf{1 7 5}$ were prepared from the reaction of terephthalaldehyde 1 with 1,3-dicarbonyl 174 and urea or thiourea in acidic medium ${ }^{81-85}$ or using silica-supported tin chloride and titanium tetrachloride as catalyst ${ }^{93}$ (Scheme 58 ).<smiles>[R][Y4](OC([R])=O)=[SH](=O)OCC</smiles>

175

\section{Scheme 58}

The trifluoromethyl derivatives of 1,4-bis(tetrahydropyrimidinone-4-yl)benzenes $\mathbf{1 7 7}$ were synthesized via one-pot condensation of terephthalaldehyde $\mathbf{1}$ with (thio)urea or guanidine and fluorinated 1,3-dicarbonyl derivatives $\mathbf{1 7 6}$ at ambient temperature using catalytic quantities of chlorotrimethylsilane (TMSCl) (Scheme 59). ${ }^{94}$<smiles>O=Cc1ccc(C=O)cc1</smiles>

1

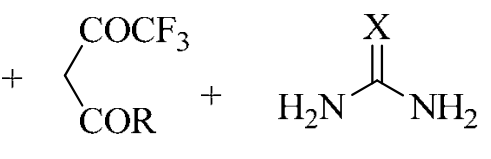

176
$\mathrm{R}=\mathrm{Me}, \mathrm{OMe}, \mathrm{CF}_{3}$ $\mathrm{X}=\mathrm{O}, \mathrm{S}, \mathrm{NH}$

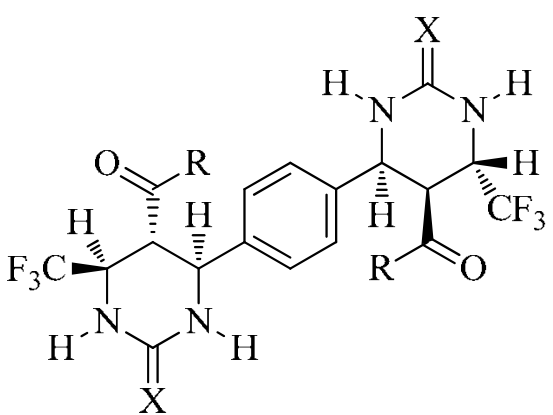

177

\section{Scheme 59}

The ternary condensation of terephthalaldehyde $\mathbf{1}$, ethyl benzoylacetate and urea or thiourea or methyl thiourea in a molar ratio 1:2:2, in ethanol containing catalytic amount of hydrochloric acid yielded the corresponding 4,4'-(1,4-phenylene)bis(1,2,3,4-tetrahydropyrimidine) 178 (Figure 24). ${ }^{89}$ 


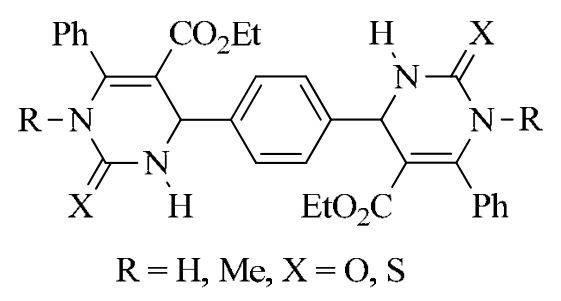

178

\section{Figure 24}

Scheme 60 outlines the synthesis of 4,4'-(1,4-phenylene)bis(2-substituted-pyrimidine) derivatives 181 from the reaction of the 3-dimethylamino-1-[4-(3-dimethylaminoacryloyl)phenyl]propenone 179 with amidine hydrochlorides 180 and sodium ethoxide. ${ }^{87}$

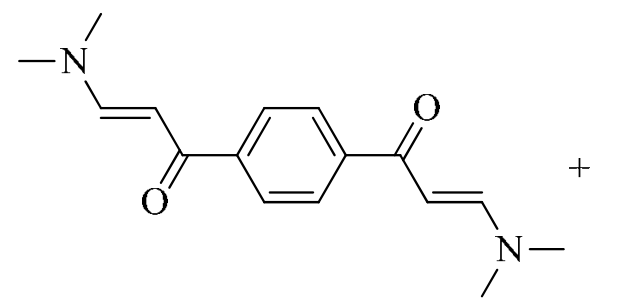

179<smiles>[R]C(N)=NCC(C)O[R11]([H])([H])O</smiles>

181

$$
\mathrm{R}=\mathrm{CH}_{3}, \mathrm{NH}_{2}
$$

\section{Scheme 60}

Also, the reaction of amidine hydrochlorides 180 with 3,3'-(1,4-phenylene)bis[1-(2-thienyl)2-propen-1-one] 182 and sodium ethoxide carried out in ethanol resulted of 4,4'-(1,4phenylene)bis(2-substituted-6-(2-thienyl)-pyrimidine) derivatives 183 (Figure 25). ${ }^{87}$<smiles>O=C(/C=C/c1cccs1)c1ccc(C(=O)/C=C/c2cccs2)cc1</smiles>

182

$$
\mathrm{R}=\mathrm{CH}_{3}, \mathrm{NH}_{2}
$$<smiles>[R]c1nc(-c2ccc(-c3cc(-c4cccs4)nc([R])n3)cc2)cc(-c2cccs2)n1</smiles>

\section{Figure 25}

Also, the reaction of amidines $\mathbf{1 8 0} \quad\left(\mathrm{R}=\mathrm{CH}_{3}\right)$ with 2,2'-(1,4-phenylene)bis(1,1dicyanoethylene) $\mathbf{1 8 4}$ in ethanol containing a catalytic amount of piperidine gave the 
corresponding 4,4'-(1,4-phenylene)bis(6-amino-5-cyano-2-substituted-pyrimidine) 185 (Scheme $61){ }^{87}$<smiles>CC(=N)N</smiles>

184<smiles>CCOC(=O)c1ccc(-c2nc(C)nc(N)c2C#N)cc1</smiles>

185

\section{Scheme 61}

Heating of the $\mathrm{N}$-[4-(2-Carboxyethyl)amino]phenyl-aspartic acid 186 with urea in acetic acid and subsequent addition of $\mathrm{HCl}$ gives the 1,1'-(1,4-phenylene)bis(dihydropyrimidine2,4(1H,3H)-dione) 187 (Figure 26). ${ }^{47}$

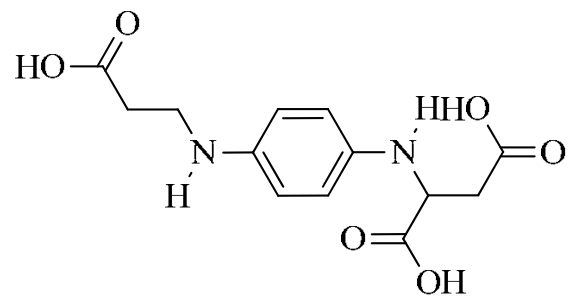

186<smiles>O=C1CCN(c2ccc(N3CCC(=O)NC3=O)cc2)C(=O)N1</smiles>

187

\section{Figure 26}

Enaminones 188 have also been reacted with 1,4-diaminobenzene 24 and formaldehyde to give 3,3'-(1,4-phenylene)bis(1-alkyl-1,2,3,4-tetrahydropyrimidine) 189 (Figure 27). ${ }^{95}$<smiles>O=C(/C=C\N[AlH2])c1ccncc1</smiles><smiles>O=C(C1=CN(c2ccc(N3CC(C(=O)c4ccncc4)=CN([Al])C3)cc2)CN([Al])C1)c1ccncc1</smiles>

188

189

$$
\mathrm{Ar}=\mathrm{C}_{6} \mathrm{H}_{5}, \mathrm{C}_{6} \mathrm{H}_{5} \mathrm{CH}_{2}
$$

Figure 27 
The reaction of 1,3-cyclohexadione 190 with terephthalaldehyde $\mathbf{1}$, and urea using silicasupported tin chloride and titanium tetrachloride as catalyst afforded 4,4'-(1,4phenylene)bis(3,4,7,8-tetrahydroquinazoline-2,5(1H,6H)-dione) 191 (Scheme 62). ${ }^{93}$<smiles>CC(C)C1NC(=O)NC(c2ccc(C3NC(=O)NC4=C3C(=O)CCC4)cc2)C1=O</smiles>

\section{Scheme 62}

The reaction of benzene-1,4-diboronic acid 22 with 6-chloropurine 192 in the presence of $\mathrm{Pd}\left(\mathrm{PPh}_{3}\right)_{4}$ and $\mathrm{K}_{2} \mathrm{CO}_{3}$ in $\mathrm{DME} / \mathrm{H}_{2} \mathrm{O}$ proceeded very smoothly giving the 1,4-bis(7-benzyl-7Hpyrrolo[2,3-d]pyrimidin-4-yl)benzene 193 (Scheme 63). ${ }^{96}$

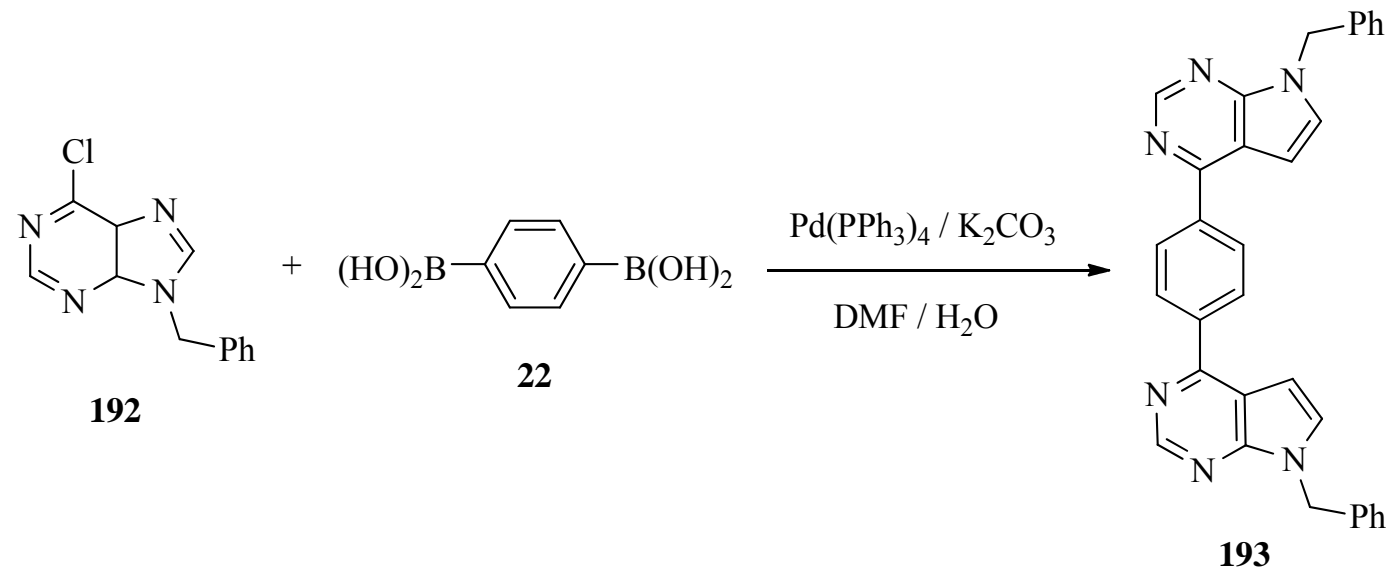

\section{Scheme 63}

When a mixture of enaminones 194, 1,4-diaminobenzene 25 and formaldehyde (2:1:4) in methanol was subjected to MWI yielded 3,3'-(1,4-phenylene)bis(1,2,3,4,7,8-hexahydroquinazolin-5(6H)-one) 195 (Scheme 64). ${ }^{97}$

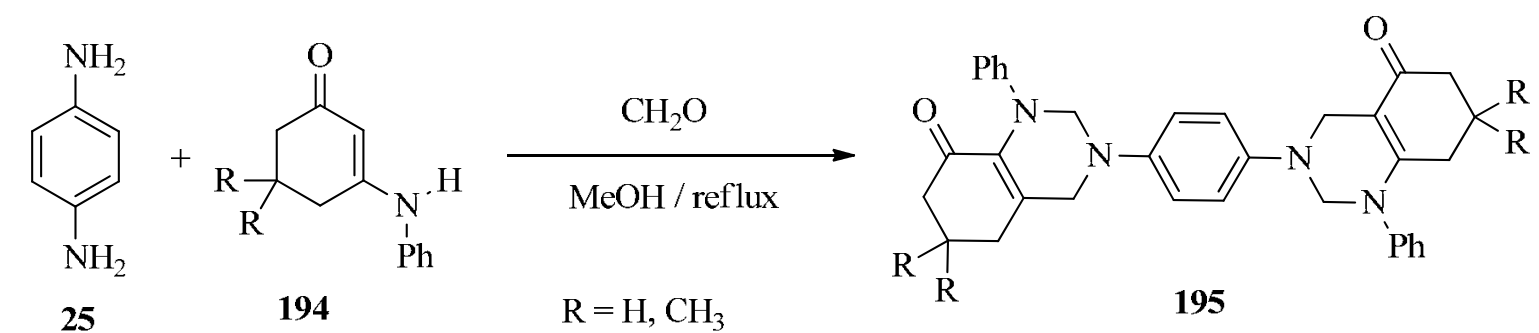

\section{Scheme 64}


The bis(pyrazino[2',3':4,5]thieno[3,2- $d]$ pyrimidin-4-yl)benzene derivatives $\mathbf{1 9 8}$ were prepared in very good yields $(85-95 \%)$ by the reaction of 1,4-phenylene diisocyanate 196 with 2 equiv of iminophosphorane 197, followed by heterocyclization on addition of secondary amines in the presence of a catalytic amount of $\mathrm{K}_{2} \mathrm{CO}_{3}$ (Scheme 65$) .{ }^{98,99}$<smiles>CCOC(=O)c1sc2nccnc2c1N=[In]</smiles>

196<smiles>[R10]Nc1nc2sc3nccnc3c2c(=O)n1-c1ccc(-n2c(N)nc3c(sc4nccnc43)c2=O)cc1</smiles>

198

\section{Scheme 65}

\subsection{1,4-Phenylene- bis-oxazines}

Refluxing 1,4-phenylenedicarbamothioyl cyanide $\mathbf{7 0}$ with two moles of salicylic acid or methyl salicylate in DMF containing a catalytic amount of triethylamine, 3,3'-(1,4-phenylene)bis(2thioxo-2,3-dihydro-benzo[e][1,3] oxazine-4-one) 199 was obtained (Scheme 66). ${ }^{49}$<smiles>N#CC(=S)Nc1ccc(I)cc1</smiles>

70<smiles>[R]OC(=O)c1ccccc1O</smiles>

$\mathrm{R}=\mathrm{H}, \mathrm{Me}$<smiles>O=c1c2ccccc2oc(=S)n1-c1ccc(-n2c(=S)oc3ccccc3c2=O)cc1</smiles>

199

\section{Scheme 66}

\subsection{1,4-Phenylene- bis-pyrazines}

The 6,6'-(1,4-phenylene)bis(5-substituted-pyrazine) 202 are prepared by cyclocondensation of bis(glyoxalyl)benzenes 200 with diaminomaleontrile 201 (Scheme 67). ${ }^{100}$<smiles>[R]C(=O)C(=O)c1ccc(C(=O)C([R])=O)cc1</smiles>

200

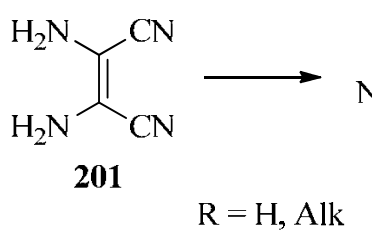<smiles>[R]c1nc(C#N)c(C#N)nc1-c1ccc(-c2nc(C#N)c(C#N)nc2[R])cc1</smiles>

202

\section{Scheme 67}




\subsection{1,4-Phenylene- bis-1,3-thiazines and their fused derivatives}

The 2,2'-(1,4-phenylene)bis(3,4-dihydro-2H-1,3-thiazine) 204 have been synthesized by the cyclocondensation of terephthalaldehyde 1 with 2 equivalents of 203 in the presence of catalytic amounts of $p$-toluenesulfonic acid in boiling ethanol. High yields of the products 204 also resulted when the reaction was performed in boiling glacial acetic acid (Scheme 68). ${ }^{101}$

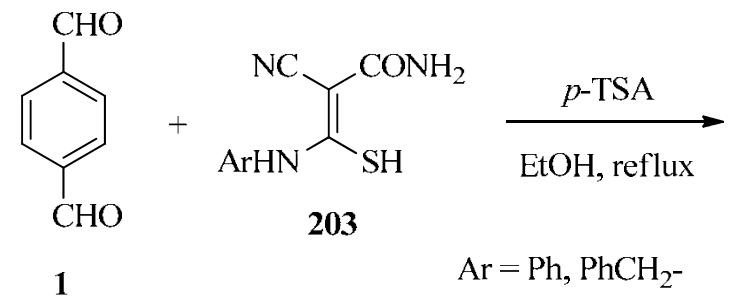<smiles>CCCCCNC1=C(C#N)C(=O)NC(c2ccc(C3NC(=O)C(C#N)=C(NCCC)S3)cc2)S1</smiles>

204

\section{Scheme 68}

Oxidation of $\mathbf{2 0 4}$ in the presence of nitrobenzene gave 2,2'-(1,4-phenylene)bis(4-oxo-6(phenylamino)-4H-1,3-thiazine-5-carbonitrile) 205 (Figure 28). ${ }^{101}$

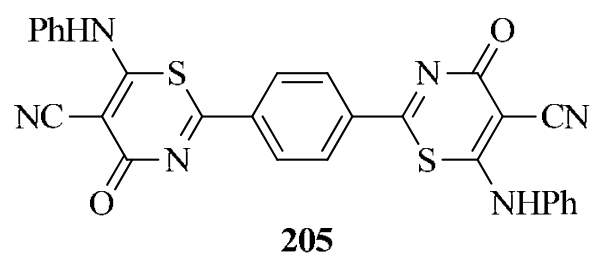

\section{Figure 28}

The condensation of 5-substituted-2,4-dihydro-3H-1,2,4-triazole-3-thione 207 with benzene1,4-diylbisacryloyl chloride 206 gave 5,5'-(1,4-phenylene)bis(5H-[1,2,4]triazolo[5,1b] $[1,3]$ thiazin-7(6H)-one) 208 (Scheme 69). ${ }^{102}$<smiles>O=C(Cl)/C=C/c1ccc(/C=C/C(=O)Cl)cc1</smiles>

$$
\mathrm{Ar}=\mathrm{C}_{6} \mathrm{H}_{5}, 4-\mathrm{H}_{3} \mathrm{CO}-\mathrm{C}_{6} \mathrm{H}_{4}, 4-\mathrm{F}-\mathrm{C}_{6} \mathrm{H}_{4}, 1 \text {-naphthyl }
$$

\section{Scheme 69}




\section{1,4-Phenylene- Bis-spiroheterocycles}

The condensation of 1,4-diaminobenzene 24 with cyclohexanone or cycloheptanone and thioglycollic acid in molar ratio 1:2:2 using dry toluene as a solvent led to 4,4'-(1,4phenylene)bis[1-thia-4-azaspiro[4.5]decan-3-one] 209 and/or 4,4'-(1,4-phenylene)bis[1-thia-4azaspiro[4.6] undecan-3-one] 210, respectively (Figure 29). ${ }^{59}$

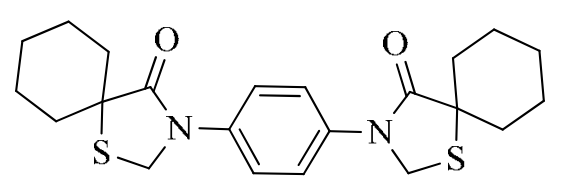

209

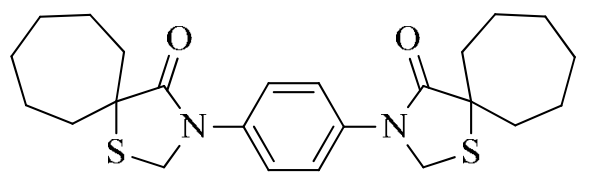

210

Figure 29

Cyclocondensation of mercaptoacetic acid with diimines $\mathbf{2 1 1}$ (prepared from two equivalents of isatin or $N$-methylisatin with one equivalent 1,4-diaminobenzene 25), was carried out under MWI to yield 3,3'-(1,4-phenylene)bis(spiro[indoline-3,2'-thiazolidinone]) 212 (Scheme 70). ${ }^{103}$<smiles>[R]N1C(=O)/C(=N\c2ccc(/N=C3\C(=O)N([R])c4ccccc43)cc2)c2ccccc21</smiles>
$\mathrm{R}=\mathrm{H}, \mathrm{Me}$<smiles>[R]N1C(=O)C2(SCC(=O)N2c2ccc(N3C(=O)CSC34C(=O)N([R])c3ccccc34)cc2)c2ccccc21</smiles>

212

\section{Scheme 70}

\section{Conclusions}

Literature data published in the last 40 years have been summarized to help the reader to find information appropriate for the high synthetic potential of 1,4-phenylenebridged bis-heterocyclic compounds. Syntheses of many biologically active heterocyclic compounds belonging to this structural class have been reported.

\section{References}

1. Katritzky, A. R.; Ramsden, C. A.; Scriven, E. F. V.; Taylor, R. J. K. Eds. In Comprehensive Heterocyclic Chemistry III; Elsevier: Oxford. 2008, pp 3-6. 
2. Gil, C.; Bräse, S. J. Comb. Chem. 2009, 9, 175.

3. Carey, J. S.; Laffan, D.; Thomson, C.; Williams, M. T. Org. Biomol. Chem. 2006, 4, 2337.

4. Dömling, A. Chem. Rev. 2006, 106, 17.

5. Rück-Braun, K.; Freysoldt, T. H. E.; Wierschem, F. Chem. Soc. Rev. 2005, 34, 507.

6. O’Mahony, G. E.; Kelly, P.; Lawrence, S. E.; Maguire, A. R. Arkivoc 2011, (i), 1.

7. Shaker, R. M. Arkivoc 2006, (ix), 59.

8. Bellina, F.; Rossi, R. Tetrahedron 2006, 62, 7213.

9. Shaker, R. M.; Aly, A. A. Phosphorus, Sulfur Silicon Relat. Elem. 2006, 181, 2577.

10. Mehta, P. D.; Sengar, N. P. S.; Pathak, A. K. Eur. J. Med.Chem. 2010, 45, 5541.

11. Bellina, F.; Cauteruccio, S.; Rossi, R. Tetrahedron 2007, 63, 4571.

12. Ispikoudi, M.; Amvrazis, M.; Kontogiorgis, C.; Koumbis, A. E.; Litinas, K. E.; Hadjipavlou-Litina, D.; Fylaktakidou, K. C. Eur. J. Med. Chem. 2010, 45, 5635.

13. Singh, H.; Yadav, L. D. S.; Bhattacharya, B. K. J. Indian. Chem. Soc. 1979, 56, 1013.

14. Desai, N. C. Indian J. Chem. Sect. B 1993, 32, 343.

15. Feng, X. M.; Chen, R.; Liu, X. C.; Zhang, Z. Y. Chin. J. Appl. Chem. 1991, 8, 28.

16. Upadhyay, P. S.; Vansdadia, R. N.; Baxi, A. J. Indian J. Chem. Sect. B 1990, $29,793$.

17. Zhang, Z. Y.; Chen, X.; Wei, L. L.; Ma, Z. L. Chem. Res. Chin. Univ. 1991, 7, 129.

18. Bhat, A. R.; Athar, F.; Azam, A. Eur. J. Med. Chem. 2009, 44, 426.

19. Reddy, D. B.; Seenaiah, B.; Eswaraiah, S.; Seshamma, T.; Reddy, M. V. R. J. Indian. Chem. Soc. 1989, 66, 893.

20. Iqbal, P. F.; Parveen, H.; Bhat, A. R.; Hayat, F.; Azam, A. Eur. J. Med. Chem. 2009, 44, 4747.

21. Nair, V.; Mathew, S. C.; Vellalath, S.; Pillai, A. N.; Suresh, E. Synthesis 2008, 4, 551.

22. Teimouri, M. B.; Bazhrang, R. Bioorg. Med. Chem. Lett. 2006, 16, 3697.

23. Yang, M. J.; Zhang, Q. H.; Wu, P.; Ye, H.; Liu, X. Polymer 2005, 46, 6266.

24. Tovar, J. D.; Rose, A.; Swager T. M. J. Am. Chem. Soc. 2002, 124, 7762.

25. Engel, N.; Steglich, W. Angew. Chem. Ed. Int. Engl. 1978, 676.

26. Reynolds, J. R.; Katritzky, A. R., Soloducho, J.; Belyakov, S.; Sotzing, G.; Pyo, M. Macromolecules 1994, 27, 7225.

27. Sotzing, G. A.; Reynolds, J. R.; Katritzky, A. R.; Soloducho, J.; Belyakov, S.; Musgrave, R. Macromolecules 1995, 28, 1679.

28. Korostova, S. E.; Mikhaleva, A. I. Zh. Org. Khim. 1982, 18, 2620.

29. Trofimov, B. A.; Mikhaleva, A. I. Novosibirsk 1984, 264.

30. Trofimov, B. A.; Markova, M. V.; Morozova, L. V.; Mikhaleva, A. I.; Shmidt, E. Yu.; Zorina, N. V.; Hyun, S. H. Polymer Sci. Ser. B 2010, 52, 193.

31. Setsune, J.; Toda, M.; Watanabe, K.; Panda, P. K.; Yoshida, T. Tetrahedron Lett. 2006, 47, 7541.

32. Flores, A. F. C.; Flores, D. C.; Oliveira, G.; Pizzuti, L.; da Silva, R. M. S.; Martins, M. A. P.; Bonacorso, H. G. J. Braz. Chem. Soc. 2008, 19, 184.

33. Habibi, D.; Marvi, O. J. Serb. Chem. Soc. 2005, 70, 579. 
34. Just, P. E.; Chan-Ching, K. I.; Lacaze, P. C. Tetrahedron 2002, 58, 3467.

35. Tsukerman, S. V.; Nikitchenko, V. M.; Maslennikova, V. P.; Bondarenko, V. E.; Lavrushin, V. F. Chem. Heterocycl.Compd. 1968, 4, 794.

36. Kanagarajan, V.; Ezhilarasi, M. R.; Gopalakrishnan, M. Spectrochimica Acta Part A 2011, $178,635$.

37. Gao, X. -G.; Yang, C. -W.; Zhang, Z. -Z.; Zeng, C. -C.; Song, X. -Q.; Hu, L. -M.; Zhong, R. -G.; She, Y. -B. Tetrahedron 2010, 66, 9880.

38. Jitchati, R.; Batsanov, A. S.; Bryce, M. R. Tetrahedron 2009, 65, 855.

39. Ivashchuk, O.; Sorokin, V. I. Tetrahedron 2009, 65, 4652.

40. Jouaiti, A.; Loï, M.; Hosseini, M. W.; De Cian, A. Chem. Commun. 2000, 2085.

41. Guerrero, A. M.; Jalon, F. A.; Manzano, B. R.; Claramunt, R. M.; Dolores Santa Maria, M.; Escolastico, C.; Elguero, J.; Rodriguez, A. M.; Maestro, M. A.; Mahia, J. Eur. J. Inorg. Chem. 2002, 3178.

42. Manzano, B. R.; Jalon, F. A.; Espino, G.; Guerrero, A.; Claramunt, R. M.; Escolastico, C.; Elguero, J.; Aranzazu Heras, M. Polyhedron 2007, 26, 4373.

43. Hasaninejad, A.; Zare, A.; Shekouhy, M. Tetrahedron 2011, 67, 390.

44. Shin, G.; Lee, J. I.; Kim, J. -H. Bull. Korean Chem. Soc. 1995, 16, 1037.

45. Braddock, D. C.; Cailleau, T.; Cansell, G.; Hermitage, S. A.; Pouwer, R. H.; Redmond, J. M.; White, A. J. P. Tetrahedron: Asymmetry 2010, 21, 2911.

46. Sung, K.; Wu, S. -H.; Chen, P. -I. Tetrahedron 2002, 58, 5599.

47. Rutkauskas, K.; Beresnevicius, Z.-I. Chem. Heterocycl. Compd. 2004, 40, 792.

48. Habib, O. M. O.; Moawad, E. B.; El-Morsy, S. S. J. Islamic Acad. Sci. 1989, 22, 135.

49. El-Sharief, A. M. Sh.; Ammar, Y. A.; Zahran, M. A.; Sabet, H. Kh. J. Chem. Res (S) 2003, 162.

50. Sangshetti, J. N.; Kokare, N. D.; Kotharkara, S. A.; Shinde, D. B. J. Chem. Sci. 2008, 120, 463.

51. Mukhopadhyay, C.; Tapaswi, P. K. Tetrahedron Lett. 2008, 49, 6237.

52. Shaabani A, Soleimani E, Maleki A, Moghimi-Rad J., Mol Divers. 2009, 13, 269.

53. Gaina, C. Chem. Bull. Politehnica Univ. (Timişoara) 2006, 51, 1.

54. Po, R.; Abis, L.; Fiocca, L.; Mansani, R. Macromolecules 1995, $28,5699$.

55. Shabarov, Yu. S.; Saginova, L. G.; Gazzaeva, R. A. Zh. Org. Khim. 1982, 18, 2627.

56. Shabarov, Yu. S.; Saginova, L. G.; Gazzaeva, R. A. Khim. Geterotsikl. Soedin. 1983, 738.

57. Gazzaeva, R. A.; Shabarov, Yu. S.; Saginova, L. G. Khim. Geterotsikl. Soedin. 1984, 309.

58. Novokreshchennykh, V. D.; Mochalov, S. S.; Lukashova, E. A.; Shabarov, Yu. S. Zh. Org. Khim. 1984, 20, 108.

59. Shaker, R. M. Phosphorus, Sulfur Silicon Relat. Elem. 1999, 149, 7.

60. Mohan, J.; Kumar, A. Indian J. Chem. 2005, 44B, 631.

61. Shaker, R. M.; Mahmoud, A. F.; Abdel-Latif, F. F. Phosphorus, Sulfur Silicon Relat. Elem. 2005, 180, 397.

62. Kotschy, A.; Farago, J.; Smith, D. M. Tetrahedron 2004, 60, 3421. 
63. Palekar, V. S.; Damle, A. J.; Shukla, S.R. Eur. J. Med. Chem. 2009, 44, 5112.

64. Klingele, M. H.; Brooker, S. Inorg. Chim. Acta 2004, 357, 1598.

65. Mobinikhaledi, A.; Foroughifar, N.; Kalhor, M.; Ebrahimi, S.; Bodaghi Fard M. A. Phosphorus, Sulfur Silicon Relat. Elem. 2011, 186, 1563.

66. Korshak, V. V.; Rusanov, A. L.; Leont'eva, S. N.; Dzhashiashvili, T. K. Khim. Geterotsikl. Soedin. 1974, 1569.

67. Blanco, G.; Quintela, J. M.; Peinador, C. Tetrahedron 2008, 64, 1333.

68. Taher, A.; Eichenseher, S.; Slawin, A. M. Z.; Tennant, G.; Weaver, G. W. J. Chem. Soc. Perkin Trans. I 2002, 1968.

69. Li, D. J.; FU, H. Q. Chin. Chem. Lett. 2006, 17, 625.

70. Zhang, X.; Tang, B.; Zhang, P.; Li, M.; Tian, W. J. Molecular Str. 2007, 846, 55.

71. Wan, J. -H.; Feng, J. -C.; Wen, G. -A.; Wang, H. -Y.; Fan, Q. -L.; Wei, W.; Huang, C. H.; Huang, W. Tetrahedron Lett. 2006, 47, 2829.

72. Bethel, P. A.; Hill, M. S.; Mahon, M. F.; Molloy, K. C. J. Chem. Soc. Perkin Trans. I 1999, 3507.

73. Fleming, A.; Kelleher, F.; Mahon, M. F.; McGinley, J.; Prajapati, V. Tetrahedron 2005, 61, 7002.

74. Vorobèv A. N.; Baranovskii, A. V.; Gaponic, P. N.; Ivashkevich, O. A. Russ. J. Org. Chem. 2010, 46, 291.

75. Bogdanowicz-Szwed, K.; Budzowski, A. Monatsh. Chem. 1999, 130, 545.

76. Feng, Y. J.; Miao, C. B.; Gao, Y.; Tu, S. J.; Fang, F.; Shi, D. Q. Chin. J. Chem. 2004, 22, 622.

77. Abdel-Latif, F. F.; Mashaly, M. M.; Mekheimer, R.; Abdel-Aleem, T. B. Z. Naturforsch. 1993, 48b, 817.

78. Tu, S.; Gao, Y.; Miao, C.; Zhu, S.; Li, T.; Zhang, X. Synth. Commun. 2004, 34, 2617.

79. Jin, T. -S.; Liu, L. -B.; Zhao, Y.; Li, T. -S. Synth. Commun. 2005, 35, 2379.

80. Shaker, R. M. Pharmazie 1996, 51, 148.

81. Tu, S.; Miao, C.; Fang, F.; Youjian, F.; Li, T.; Zhuang, Q.; Zhang, X.; Zhu, S.; Shi, D. Bioorg. Med. Chem. Lett. 2004, 14, 1533.

82. Izuhara, D.; Swager, T. M. J. Am. Chem. Soc. 2009, 131, 17724.

83. Cave, G. W. V.; Raston, C. L. J. Chem. Soc. Perkin Trans. I 2001, 3258.

84. Winter, A.; van den Berg, A. M. J.; Hoogenboom, R.; Kickelbick, G.; Schubert, U. S. Synthesis 2006, 2873.

85. Shaker, R. M.; Abdel-Latif, F. F. J. Chem. Res. (S) 1997, 294.

86. Ghozlan, S. A. S.; Hassanien, A. Z. A. Tetrahedron 2002, 58, 9423.

87. Shaker, R. M. Heteroatom. Chem. 2005, 16, 507.

88. Fernández-Mato, A.; Blanco, G.; Quintela, J. M.; Peinador, C. Tetrahedron 2008, 64, 3446.

89. Shaker, R. M.; Mahmoud, A. F.; Abdel-Latif, F. F. Phosphorus, Sulfur Silicon Relat. Elem. 2000, 160, 207. 
90. Feng, Y. -J.; Zhang, X. -J.; Miao, C. -B.; Jiang, H.; Tu, S. -J. Youji Huaxue. 2004, 24, 950. Chem. Abstr. 2004, 142, 93657.

91. Aly, A. A.; Mohamed, N. K.; Hassan, A. A.; Mourad, A.-F. E. Tetrahedron 1999, 55, 1111.

92. Saverchenko, A. N.; Kaminskii, V. A.; Tilichenko, M. N. Khim. Geterotsikl. Soedin. 1972, 1232.

93. Niknam, K.; Hasaninejad, A.; Arman, M. Chin. Chem. Lett. 2010, 21, 399.

94. Azizian, J.; Mirza, B.; Mojtahedi, M. M.; Abaee, M. S.; Sargordan, M. J. Fluorine. Chem. 2008, 129, 1083.

95. Vishwakarma, J. N.; Dutta, M. C.; Chanda, K.; Das, B.; Laskar, M. A.; Nongkhlaw, R. L. Arkivoc 2009, (xiii), 131.

96. Havelková, M.; Dvořák, D.; Hocek, M. Tetrahedron 2002, 58, 7431.

97. Dutta, M. C.; Chanda, K.; Nongkhlaw, R. L.; Vishwakarma, J. E. J. Chem. 2010, 7, 281.

98. Blanco,G.; Quintela, J. M.; Peinador, C. Tetrahedron 2007, 63, 2034.

99. Blanco, G.; Fernández-Mato, A.; Quintela, J. M.; Peinador, C. Tetrahedron 2008, 64, 11136.

100. Tadokoro, K.; Shoji, M.; Nanba, M.; Shimada, T.; Tanaka, C. Jpn Kokai. Jpn. Kokai Tokkyo Koho JP 2001002661 A2; Chem. Abstr. 2001, 134, 86278.

101. Shaker, R. M.; Ibrahim, Y. R.; Abdel-Latif, F. F.; Hamoda, A. Z. Naturforsch 2010, 65b, 1148 .

102. Kudryavtsev, A. A.; Lozinskii, M. O. Russ. J. Org. Chem. 2004, 40, 232.

103. Azizian, J.; Morady, A. V.; Jadidi, K.; Mehrdad, M.; Sarraffi, Y. Synth. Commun. 2000, 30, 537.

\section{Authors' Biographies}

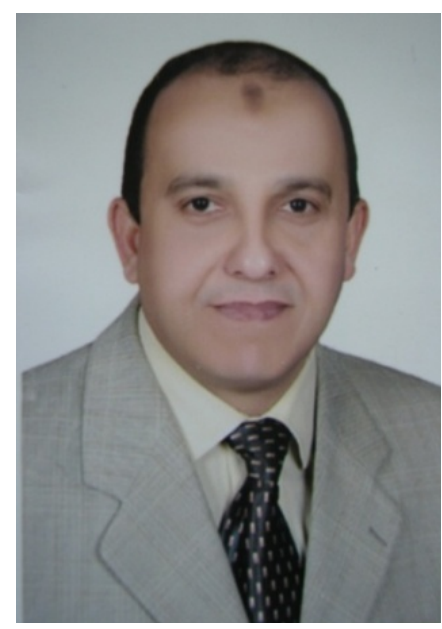

Raafat M. Shaker was born in 1963 in Minia, Egypt. He is a Professor of Organic Chemistry in Chemistry Department, Faculty of Science, Organic Division, El-Minia University, 61519 - El Minia, Egypt. He received both his B.Sc. degree (1985) and M.Sc. degree (1989) from Minia 
University, Egypt. He was awarded with a channel system program to complete his Ph.D. program under the supervision of Prof $\mathrm{Dr} \mathrm{H}$. H. Otto, in the field of Heterocyclic chemistry for two years at Albert - Ludwigs - Freiburg University, Freiburg, Germany (1992 - 1994). In 1999 he was awarded the DFG scholarship for two months with Prof Dr Hartmut Laatsch, Department of Organic Chemistry, University of Goettingen, Goettingen, Germany. He was awarded for one year (July, 2002 - July, 2003) the post doctoral scientific grant for International Authors from the Royal Society of Chemistry (FRSC) and collaborated with Prof. Dr Grahame Mackenzie, University of Hull, Department of Chemistry, Hull, UK. His research is focused on the synthesis of heterocyclic compounds which may have prospective biological and pharmaceutical activities. He contracted with Al-Jouf University, Chemistry department, Faculty of Science, Al-Jouf, Sakaka, Kingdom of Saudi Arabia (2009 - Now). 